\title{
DIETARY SOY PROTEIN REDUCES EARLY RENAL DISEASE PROGRESSION AND ALTERS PROSTANOID PRODUCTION IN OBESE $\mathrm{fa} / \mathrm{fa}$ ZUCKER RATS
}

\author{
BY \\ SUN-YOUNG HWANG
}

A thesis submitted to the faculty of graduate studies in partial fulfillment of the requirements for a degree of

\section{MASTER OF SCIENCE}

Department of Human Nutritional Sciences

University of Manitoba

Winnipeg, Manitoba

R3T 2N2

(C) SUN-YOUNG HWANG, 2006 


\title{
THE UNIVERSITY OF MANITOBA
}

\section{FACULTY OF GRADUATE STUDIES \\ $* * \dot{*} * *$}

COPYRIGHT PERMISSION

\section{DIETARY SOY PROTEIN REDUCES EARLY RENAL DISEASE PROGRESSION AND ALTERS PROSTANOID PRODUCTION IN OBESE $f a / f a$ ZUCKER RATS}

BY

\author{
Sun-Young Hwang
}

\begin{abstract}
A Thesis/Practicum submitted to the Faculty of Graduate Studies of The University of Manitoba in partial fulfillment of the requirement of the degree

MASTER OF SCIENCE
\end{abstract}

Sun-Young Hwang $\subset 2006$

Permission has been granted to the Library of the University of Manitoba to lend or sell copies of this thesis/practicum, to the National Library of Canada to microfilm this thesis and to lend or sell copies of the film, and to University Microfilms Inc. to publish an abstract of this thesis/practicum.

This reproduction or copy of this thesis has been made available by authority of the copyright owner solely for the purpose of private study and research, and may only be reproduced and copied as permitted by copyright laws or with express written authorization from the copyright owner. 


\begin{abstract}
The growing epidemic of obesity in adults, as well as in children, is occurring throughout the world. It affects not only the individual's physical and mental health but carries substantial costs for the nation's economy. With the rising incidence of obesity and the metabolic syndrome, nephropathy associated with obesity also has increased. Soy protein can ameliorate disease in several models of chronic kidney disease. It also may alter the production of renal prostanoids, which may play a role in the glomerular hyperfiltration in obesityassociated nephropathy (OAN). Therefore, the effect of dietary soy protein on early disease progression and prostanoid production in OAN was examined in the obese fa/fa Zucker rat. Six-week-old male fa/fa and lean Zucker rats were offered diets ad libitum containing $17 \%$ protein from either soy protein or egg white protein for 8 weeks. Mean glomerular volume (MGV) and proteinuria were determined to assess early kidney changes and kidney function. Renal prostanoids [thromboxane $\mathrm{B}_{2}\left(\mathrm{TXB}_{2}\right)$, stable metabolite of $\mathrm{TXA}_{2} ; 6$-keto prostaglandin $F_{1 \alpha}$ (6-keto $P F_{1 a}$ ), stable metabolite of $\mathrm{PG}_{2}$; and prostaglandin $E_{2}$ $\left.\left(\mathrm{PGE}_{2}\right)\right]$ were determined by enzyme immunoassay. Renal protein and mRNA levels of cytosolic phospholipase $\mathrm{A}_{2}$ (CPLA $)$, cyclooxygenase-1 (COX-1), and COX-2 were determined by western immunoblotting and QRT-PCR. Feed consumption, body and kidney weights were significantly greater in fa/fa compared to lean rats. The fa/fa rats had $43 \%$ larger MGV and $169 \%$ higher proteinuria, reflecting early development of nephropathy. Soy protein feeding did not alter body weights or proteinuria but did result in $6 \%$ lower kidney weights
\end{abstract}


( $\mathrm{g} / 100 \mathrm{~g}$ body weight) and $16 \%$ lower MGV. Prostanoid production in these

kidneys was primarily due to COX-2 activity. Renal prostanoids were generally

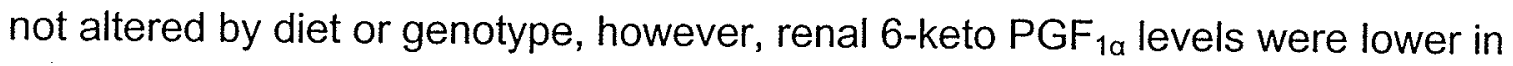
fa/fa rats fed soy protein. Renal $\mathrm{TXB}_{2} / \mathrm{PGE}_{2}$ ratios were not different in rats given soy protein compared to egg white protein while renal $\mathrm{TXB}_{2} / 6$-keto $\mathrm{PGF}_{1 a}$ ratios were higher and 6-keto $\mathrm{PGF}_{1 \mathrm{~d}} / \mathrm{PGE}_{2}$ ratios were lower, indicating that dietary soy protein reduces renal 6-keto $P G F_{1 \alpha}$ levels. The attenuation of early nephropathy in fa/fa rats by dietary soy protein is associated with lower 6-keto PGF 1 l levels. This may affect the glomerular hyperfiltration observed in OAN. 


\section{ACKNOWLEDGEMENTS}

I would like to express my thanks to God, the creator and dream giver to me all the time. Every time I am so excited to find out your purpose why you put me on this planet to do and your forever love makes me alive.

I would also like to thank my supervisor, Dr. Harold Aukema for all his time, sincere assistance, and support. Thank you to my committee members, Dr. Carla Taylor and Dr. Karmin O for agreeing to be my committee members and their guidance. The guidance I have received throughout this research experience has been greatly appreciated.

Thank you to Tasha Ryz and Danielle Stringer for analysis of urine parameters. Thank you to Lori Warford-Woolgar and Dielle Herchak who spent a great time teaching me the western immunoblotting procedure and image analysis and to my lab friends, Deepa Sankaran, Claudia Yu-Chen Peng, and Andrew Wakefield for their friendship.

Last but not least, I would like to thank my family and friends for their great love, encouragement, and support over the years. 


\section{TBALE OF CONTENTS}

$\begin{array}{lr}\text { ABSTRACT } & \mathrm{i} \\ \text { ACKNOWLEDGEMENTS } & \mathrm{iii} \\ \text { TABLE OF CONTENTS } & \text { iv } \\ \text { LIST OF ABBREVIATONS } & \text { vii } \\ \text { LIST OF TABLES } & \mathrm{ix} \\ \text { LIST OF FIGURES } & \mathrm{X}\end{array}$

\section{LITERATURE REVIEW}

\subsection{Introduction}

1.1.1 A Worldwide Epidemic: Obesity

1.1.2 Childhood Obesity 3

1.1.3 Metabolic Syndrome 4

1.1.4 Obesity-Associated Nephropathy (OAN) 6

1.1.5 The Mechanism of OAN 11

1.2 Dietary Intervention in Renal Disease

1.2.1 Fat and Renal Disease Progression 13

1.2.2 Protein and Renal Disease Progression 15

1.2.3 Dietary Soy Protein and Renal Disease 17

\subsection{Prostanoids}

1.3.1 Production of Prostanoids from Cyclooxygenase Enzymes 20

1.3.2 Prostanoid Enzymes and Prostanoid Production in Renal Disease $\quad 23$

1.3.3 Prostanoid Production and Dietary Interventions 25

1.4 The Obese fa/fa Zucker Rat $\quad 27$ 
2. DIETARY SOY PROTEIN REDUCES EARLY RENAL DISEASE

PROGRESSION AND ALTERS PROSTANOID PRODUCTION IN OBESE

fa/fa ZUCKER RATS

2.1 Abstract

2.2 Introduction

2.3 Materials and Methods

2.3.1 Animals and Diet

2.3.2 Glomerular Size

2.3.3 Immunoblotting

2.3.4 Prostanoid Production and COX Activity

2.3.5 Quantitative RT-PCR

2.3.6 Statistical Analysis

2.4 Results

2.5 Discussion

3. OVERALL DISCUSSION

6. REFERENCES

7. APPENDIX

7.1 Mean Glomerular volume (MGV)

7.2 Measurement of Steady-State Protein Levels of Enzymes Involved in Prostanoid Production 
7.2.1 Lyophilization of Kidneys

7.2.2 Homogenization of Kidneys

7.2.3 Total Protein Determination

7.2.4 Western Immunoblotting

7.3 Measurement of Kidney Function

7.3.1 Urine Creatinine

7.3.2 Serum Creatinine

7.3.3.Creatinine Clearance

7.4 Prostanoid Production and COX Activity

7.5 Effects of Dietary Soy Protein on Urine and Serum Parameters in Obese fa/fa Zucker rats 


\section{LIST OF ABBREVIATOINS}

AA
APS
BCA
BMI
BSA
CLA
COX
COX-1
COX-2
CPLA
CTL
CVD
Cytosolic cPLA
DGLA
DM
DM-2
EPA
ERPF
ESRD
fa/fa
FF
GFR
IDV
IgG
Lean
mA
MGA
MGV
mRNA
NHANES
OAN
Particulate cPLA

PBF
PBS
PGE 2
6-keto PGF $1_{\alpha}$
PGI
PKD
PREVEND
QRT-PCR

arachidonic acid

ammonium persulfate

bicinchoninic acid

body mass index

bovine serum albumin

conjugated linoleic acid

cyclooxygenase

cyclooxygenase-1

cyclooxygenase- 2

cytosolic phospholipase $A_{2}$

control diet

cardiovascular disease

cytosolic phospholipase $A_{2}$ present in cytosolic fraction dihomo-gamma-linolenic acid

diabetes mellitus

type 2 diabetes mellitus

eicosapentaenoic acid

effective renal plasma flow

end-stage renal disease

obese fa/fa Zucker rat

filtration fraction

glomerular filtration rate

integrated density value

immunoglobulin $\mathrm{G}$

lean Zucker rat

milliamps

mean glomerular area

mean glomerular volume

messenger ribonucleic acid

National Health and Nutrition Examination Survey

obesity-associated nephropathy

cytosolic phospholipase $A_{2}$ present in particulate

fraction

phosphate-buffered formalin

phosphate-buffered saline

prostaglandin $\mathrm{E}_{2}$

6-keto prostaglandin $F_{1 a}$

prostaglandin $\mathrm{I}_{2}$

polycystic kidney disease

Prevention of Renal and Vascular End Stage Disease study

quantitative reverse-transcriptase-polymerase chain

reaction 
rpm

RT-PCR

SDS

SDS-PAGE

SEM

TBS

TEMED

tris-HCL

$\mathrm{TXA}_{2}$

$\mathrm{TXB}_{2}$

WHO

ZDF revolutions per minute

reverse-transcriptase-polymerase chain reaction sodium dodecyl sulfate sodium dodecyl sulfate-polyacrylamide gel electrophoresis

standard error of the mean

tris base solution

N,N,N',N',-tetramethylethylenediamine

tris (hydroxymethyl) aminomethane-hydrochloric acid thromboxane $\mathrm{A}_{2}$

thromboxane $\mathrm{B}_{2}$

World Health Organization

Zucker Diabetic Fatty rats 


\section{LIST OF TABLES}

Table 1 Body weight classifications in adults 2

Table 2 Risk factors for the metabolic syndrome 5

Table 3 The five stages of chronic kidney disease 9

Table 4 Diet formulation 34

Table 5 Effects of dietary soy protein on feed intake, body and kidney weights, proteinuria, and creatinine clearance in obese fa/fa Zucker rats

Table 6 Effects of dietary soy protein on endogenous prostanoid levels in kidneys of obese fa/fa Zucker rats

Table 7 Effects of dietary soy protein on in vitro steady-state prostanoid levels in kidneys of obese fa/fa Zucker rats

Table 8 Effects of dietary soy protein on total COX activity in kidneys of obese fa/fa Zucker rats

Table 9 Effects of dietary soy protein on COX-2 activity in kidneys of obese fa/fa Zucker rats 


\section{LIST OF FIGURES}

Figure 1 Effects of dietary soy protein on mean glomerular

volume (MGV) in obese fa/fa Zucker rats

Figure 2 Kidney cross sections stained with eosin and hematoxylin

Figure 3 Effects of dietary soy protein on $\mathrm{TXB}_{2} / 6$-keto $\mathrm{PGF}_{1 \mathrm{a}}$ ratio in kidneys of obese fa/fa Zucker rats

Figure 4 Effects of dietary soy protein on 6-keto $\mathrm{PGF}_{1 \mathrm{a}} / \mathrm{PGE}_{2}$ ratio in kidneys of obese fa/fa Zucker rats

Figure 5 Effects of dietary soy protein on $\mathrm{TXB}_{2} / \mathrm{PGE}_{2}$ ratio in kidneys of obese fa/fa Zucker rats

Figure 6 Effects of dietary soy protein on relative cytosolic and particulate $\mathrm{CPLA}, \mathrm{COX}-1$, and $\mathrm{COX}-2$ protein expression

Figure 7 Effects of dietary soy protein on relative $\mathrm{CPLA}_{2}, \mathrm{COX}-1$, and COX-2 mRNA expression 


\section{Literature Review}

\subsection{Introduction}

\subsubsection{A Worldwide Epidemic: Obesity}

The prevalence of obesity is increasing rapidly in many parts of the world. Over the last two to three decades, obesity has transformed from a relatively minor public health issue to a major threat to public health. This transformation is now increasingly being seen throughout the world. Hence, it seems reasonable to describe obesity as a public health crisis that severely impairs the health and quality of life of people.

In populations in the world, the prevalence of obesity is high in both men and women, as well as even in children. In Canada, $23 \%$ of adults are obese and the incidence of obesity is rising with $9 \%$ of children being considered obese (Statistic Canada, 2004). The growing obesity epidemic also affects direct and indirect costs for the nation's economy. Urgent action, therefore, is required to reverse current trends.

Obesity, defined as a body mass index (BMI) of $30 \mathrm{~kg} / \mathrm{m}^{2}$ and higher, is a complex condition that has its origin in the interaction between an individual's genetic factors, eating behavior, cellular metabolism, life style, and cultural background of the community as well as socio-economic status (Table 1). Obesity is associated with increased risk of a number of disorders and there is evidence to suggest a strong relationship between obesity and metabolic and cardiovascular risk factors such as high blood pressure, dyslipidemia, hyperinsulinemia and/or insulin resistance (Hall et al., 2002; Jong 2002). In 
Table 1. Body weight classifications in adults ${ }^{1}$

\begin{tabular}{|c|c|c|}
\hline $\begin{array}{c}\text { Body Mass Index } \\
\left(\mathrm{kg} / \mathrm{m}^{2}\right)\end{array}$ & Classification & Description \\
\hline$<18.5$ & Underweight & $\begin{array}{c}\text { Might be associated with } \\
\text { health problems }\end{array}$ \\
\hline $18.5-24.9$ & Normal weight & $\begin{array}{c}\text { Good weight for most } \\
\text { people }\end{array}$ \\
\hline $25.0-29.9$ & Overweight & $\begin{array}{c}\text { Increasing risk of } \\
\text { developing health } \\
\text { problems }\end{array}$ \\
\hline$\geq 30$ & Obese & $\begin{array}{c}\text { High risk of developing } \\
\text { health problems }\end{array}$ \\
\hline
\end{tabular}

${ }^{1}$ Adapted from Kim, 2004; World Health Organization, 2000 
addition, obesity also contributes to psychological and social burdens such as social stigma, low self-esteem, reduced mobility, and a poorer quality of life.

\subsubsection{Childhood Obesity}

A rapid increase in the prevalence of obesity among children has been documented in many countries. It is recently estimated that $7 \%$ of children in the world are obese, with the U.S. having the highest prevalence (Speiser et al., 2005).

Since children's development varies with age, and boys and girls develop at different rates, the use of BMI to assess body weight in children requires growth and gender considerations. Therefore, BMI values for children and youth are specific to both age and gender. The term obesity in children and youth as defined by Centers for Disease Control and Prevention (CDC) refers to children between the ages of 2 and 18 years with BMls equal to or greater than the $95^{\text {th }}$ percentile (Kuczmarski et al., 2000).

The national surveys from the U.S. done between 1963 and 1991 found that since 1980 the number of overweight children has doubled and the number of overweight adolescents has tripled (Troiano et al., 1995). Moreover, the Bogalusa Heart Study reported that the state of being overweight or obese continues to persist into young adulthood, where $58 \%$ of overweight adolescent children remained overweight as young adults (Jiang et al., 1995).

It has been reported that there was a significant increase in the prevalence of hypertension and dyslipidemia in overweight adolescents when followed up in 
later years (Srinivasan et al., 1996). A significant increase in mortality, especially that due to cardiovascular disease, has also been reported in long-term follow-up studies of overweight children (Hoffmans et al., 1988; Mossberg, 1989; Must et al., 1992). The impact of childhood obesity on psychological morbidity, such as low self-esteem, behavioral problems, and obstructive sleep apnea, which were once considered adult diseases, are now being observed in children with obesity (Reilly et al., 2003). Therefore, the growing obesity crisis will need to be addressed at individual, family, community, national and global levels to ameliorate the health consequences of obesity in children.

\subsubsection{Metabolic Syndrome}

The term metabolic syndrome, also called "syndrome X", is used to describe the co-existence of several metabolic characteristics. The metabolic syndrome, as defined in the Third Report of the National Cholesterol Education Program (NCEP, 2002), is defined as the presence of three or more of the following risk determinants (Table 2): (1) abdominal obesity (increased waist circumference); (2) elevated triglycerides; (3) low HDL cholesterol; (4) hypertension; and (5) elevated fasting glucose.

The metabolic syndrome is recognized as an independent risk factor for the development of type 2 diabetes mellitus (DM) (Lorenzo et al., 2003). Since type 2 DM takes years to develop after signs of the metabolic syndrome are present, the pre-diabetic state of the metabolic syndrome can be considered as a warning sign (Goldstein, 2003). Therefore, it is important to initiate interventions at this 
Table 2. Risk factors for the metabolic syndrome ${ }^{1}$

\begin{tabular}{|c|c|c|}
\hline $\begin{array}{c}\text { Metabolic Syndrome Risk } \\
\text { Factor }\end{array}$ & $\begin{array}{c}\text { Defining Level for } \\
\text { Men }\end{array}$ & $\begin{array}{c}\text { Defining Level for } \\
\text { Women }\end{array}$ \\
\hline $\begin{array}{c}\text { Abdominal Obesity } \\
\text { (or waist circumference) }\end{array}$ & $>102 \mathrm{~cm}$ & $>88 \mathrm{~cm}$ \\
\hline Triglycerides $^{2}$ & $\geq 150 \mathrm{mg} / \mathrm{dl}$ & $\geq 150 \mathrm{mg} / \mathrm{dl}$ \\
\hline HDL Cholesterol ${ }^{2}$ & $<40 \mathrm{mg} / \mathrm{dl}$ & $<50 \mathrm{mg} / \mathrm{dl}$ \\
\hline Blood Pressure & $\geq 130 / 85 \mathrm{mmHg}$ & $\geq 130 / 85 \mathrm{mmHg}$ \\
\hline Fasting Glucose & $\geq 110 \mathrm{mg} / \mathrm{dl}$ & $\geq 110 \mathrm{mg} / \mathrm{dl}$ \\
\hline
\end{tabular}

\footnotetext{
${ }^{1}$ Adapted from Chen et al., 2004 and National Cholesterol Education Program, 2002

${ }^{2} \mathrm{HDL}=$ high-density lipoprotein
} 
early stage of disease. Moreover, the metabolic syndrome is not only a health concern for the adult, but is now becoming a problem for young people as well.

In 2004, Lambert et al. reported based on a study conducted in Quebec, the overall prevalence of the metabolic syndrome in youth in Canada was $11.5 \%$. Considering the average age of the participants in that study, 9, 13, or 16 years of age, this prevalence is of great concern. The metabolic syndrome is associated with an increased risk of chronic kidney disease and its association with kidney disease has been reported in childhood as well (Abrass, 2004). Obese children, with an average age of 12.9 years, had a significantly higher urinary albumin to creatinine ratio compared to children of normal weight. Among the obese children, the presence of several cardiovascular risk factors, such as hyperinsulinemia, impaired glucose tolerance, and hypercholesterolemia, were all associated with a significantly higher urinary albumin to creatinine ratio compared to those that did not have these risk factors (Csernus et al., 2005). It is evident from these studies that strategies to prevent and/or delay chronic kidney disease must be started before a clinical disease such as DM is diagnosed. Specifically, these strategies need to be initiated in the early stage of obesity.

\subsubsection{Obesity-Associated Nephropathy (OAN)}

The role of obesity in DM and diabetic nephropathy is well-recognized. However, the impact of obesity on the kidney has not received much attention so far. Therefore, this thesis is focused on bringing attention to the impact of obesity on the progression of kidney disease. 
As obesity is associated with the two most common causes of end stage renal disease (ESRD), which are DM and hypertension, it seems likely that obesity may greatly increase the risk of ESRD. The Okinawa Dialysis Study registry found the cumulative incidence of ESRD to increase from the lowest BMI quartile $(2.5$ case $/ 1,000)$ to the highest BMI quartile $(5.8$ case $/ 1,000)$ in a screening program (Iseki et al., 2004).

In 2000, Praga et al. demonstrated the long-term effects of obesity on the kidney in a follow-up study of 73 patients who had undergone unilateral nephrectomy. Fourteen of the 73 patients were obese at the time of nephrectomy in that study. At the 20 years follow-up, it was found that most of the non-obese subjects but only $30-40 \%$ of the obese subjects still had normal renal function. In 2001, Bonnet et al. reported that the presence of an elevated BMI $\left(\geq 25 \mathrm{~kg} / \mathrm{m}^{2}\right)$ at the time of renal biopsy in 162 patients with $\lg A$ nephropathy was correlated with the severity of pathological abnormalities and with clinical progression to ESRD. In 1986, Kasiske et al. investigated the type of renal abnormalities seen in obese patients. This study compared the clinical and histological patterns in 17 patients with massive obesity (mean weight $126 \mathrm{~kg}$ ) and marked proteinuria with control group of 34 patients with similar clinical presentation but normal body weight (mean weight $68 \mathrm{~kg}$ ). Although urinary protein excretion was similar in the two groups, serum albumin was higher in the obese subjects. With respect to the histological data, most of the obese patients had a focal glomerulosclerosis while most of the control subjects had a minimal change nephritic syndrome. 
In the initial stages of renal disease, glomerular filtration rate (GFR) tends to increase due to increased glomerular capillary pressure, called glomerular hyperfiltration (Mogensen et al., 1990) and kidney damage is evidenced by structural and/or functional abnormalities (National Kidney Foundation, 2002). Five stages of chronic kidney disease have been identified (Table 3). Stage 5 , also known as ESRD, represents complete kidney failure. At this point, dialysis or transplantation is required for patient survival (National Kidney Foundation, 2002). In 2002, the prevalence of ESRD in the U.S. was 1,435 per million population (USRDS, 2004).

It has previously been shown that an increased BMI is associated with microalbuminuria (Ribstein et al., 1995). A study to determine the impact of obesity on renal function in the general population was completed in a subanalysis of the Prevention of Renal and Vascular End Stage Disease study (PREVEND), which was initiated to study the impact of microalbuminuria on renal and cardiovascular risk in the general population (Hillege et al., 2001; PintoSietsma et al., 2000). In the general population aged 28-75 years old, microalbuminuria was found to be present in $16.4 \%$ of subjects with DM, $11.5 \%$ of those with hypertension and $6.6 \%$ of healthy subjects who were not known to have either DM or hypertension (Hillege et al., 2001).

So what causes microalbuminuria in these non-diabetic and nonhypertensive subjects? Data including two 24-hour urine collections to measure 24 hour urinary albumin excretion of 8592 subjects were examined to address this question (Pinto-Sietsma et al., 2000). Microalbuminuria was defined 
Table 3. The five stages of chronic kidney disease ${ }^{1}$

\begin{tabular}{|c|c|c|c|}
\hline Stage & Characteristics & $\begin{array}{c}\mathrm{GFR}^{2} \\
\left(\mathrm{~mL} / \mathrm{min} / 1.73 \mathrm{~m}^{2}\right)\end{array}$ & Albumin Excretion \\
\hline Stage 1 & $\begin{array}{c}\text { Glomerular hyperfiltration } \\
\text { \& hypertropathy } \\
\text { with normal or increased GFR }\end{array}$ & $\geq 90$ & May be increased \\
\hline Stage 2 & $\begin{array}{l}\text { Expending mesangium with mild decreased } \\
\text { GFR }\end{array}$ & $60-89$ & $<30-300 \mathrm{mg} / 24 \mathrm{hr}$ \\
\hline Stage 3 & Moderate decreased GFR & $30-59$ & $\begin{array}{c}30-300 \mathrm{mg} / 24 \mathrm{hr} \\
\text { (microalbuminuria) }\end{array}$ \\
\hline Stage 4 & Severe decreased GFR & $15-29$ & $\begin{array}{c}>300 \mathrm{mg} / 24 \mathrm{hr} \\
\text { (macroalbuminuria) }\end{array}$ \\
\hline Stage 5 & ESRD $^{3}$ & $<15$ & Decreasing \\
\hline
\end{tabular}

\footnotetext{
${ }^{1}$ Aadapted from Gillis, 1998; Mogensen et al., 1987; National Kidney Foundation, 2002

${ }^{2}$ GFR = glomerular filtration rate

${ }^{3} \mathrm{ESRD}=$ end-stage renal disease
} 
according to the classical criterion of $30-300 \mathrm{mg}$ albumin excreted per 24 hour (Table 3). Since data from 542 subjects were excluded from this analysis because urinary albumin excretion was not reliable or data was otherwise missing, the data of 8050 subjects were used. BMI was classified as normal body mass $\left(<25 \mathrm{~kg} / \mathrm{m}^{2}\right)$, overweight $\left(25-29.9 \mathrm{~kg} / \mathrm{m}^{2}\right)$, or obese $\left(>30 \mathrm{~kg} / \mathrm{m}^{2}\right)$. In men, about $47 \%$ were overweight and $14 \%$ were obese, while among women, $34 \%$ were overweight and $16 \%$ were obese. In both genders, a higher BMI was associated with greater 24-hour urinary albumin excretion. In men, the prevalence of microalbuminuria increased from $9.5 \%$ in those with a normal body weight to $18.3 \%$ in those who were overweight and to $29.3 \%$ in those with obvious obesity. In women, these percentages were $6.6,9.2$, and $16.0 \%$, respectively. Multivariate analysis also showed that BMI was independently associated with urinary albumin excretion at increasing BMI in women (Verhave et al., 2002).

As GFR starts to decrease, urinary albumin excretion rises further to macroproteinuric ranges. In non-diabetic subjects, creatinine clearance was higher in subjects with a high normal albumin excretion (15-30 $\mathrm{mg} / \mathrm{day})$ than in controls (albumin excretion $0-15 \mathrm{mg} /$ day) and was still elevated in microalbuminuric (albumin excretion 30-300 $\mathrm{mg} /$ day) persons while it was lower in the macroproteinuric (albumin loss $>300 \mathrm{mg} / \mathrm{day}$ ) subjects (Pinto-Sietsma et al., 2000). This pattern is similar to that described in DM, with initial glomerular hyperfiltration, followed by gradual loss of renal function. Therefore, this suggests that the higher risk for microalbuminuria is associated with a higher risk for 
glomerular hyperfiltration and ultimately impaired glomerular filtration in nondiabetic subjects. These data are compatible with renal function studies, which have shown that obese subjects have an elevated renal blood flow and GFR (Jong et al., 2002).

The other major outcome of chronic kidney disease, aside from ESRD, is cardiovascular disease (CVD) (National Kidney Foundation, 2002). CVD is also the leading cause of death in patients with kidney failure. Dialysis patients from 25 to 35 years of age have a mortality risk from CVD that is 500 fold higher compared to the general population (National Kidney Foundation, 2002).

Even though the risk of developing kidney failure depends on the level of kidney function and the rate of decline of kidney function (National Kidney Foundation, 2002), earlier detection and appropriate interventions may delay kidney disease and the rate of decline of kidney function. This could potentially delay the diagnosis of ESRD and subsequent risk of CVD.

\subsubsection{The Mechanism of OAN}

What then is the mechanism behind the OAN? Hyperfiltration in non-diabetic obese individuals occurs because of increased transcapillary hydraulic pressure due to dilatation of the afferent arteriole without a change in diameter of the efferent arteriole. In 1995, Ribstein et al. studied non-diabetic subjects with BMIs between 27 and $40\left(\mathrm{~kg} / \mathrm{m}^{2}\right)$ and reported that GFR and effective renal plasma flow (ERPF) were increased in overweight compared with lean subjects. Chagnac and colleagues did a similar study demonstrating an increased GFR, 
ERPF, filtration fraction (FF), and urinary albumin excretion rate in obese subjects. The data show renal hyperfiltration in non-diabetic obese individuals. Moreover, the impact of elevated BMI on renal hemodynamics is not limited to overt obesity, as even subjects with $\mathrm{BMI}<30 \mathrm{~kg} / \mathrm{m}^{2}$ have elevated FF from a higher GFR relative to ERPF suggesting higher glomerular pressure (Bosma et . al., 2004).

Hormonal factors also may be involved in these mechanisms. Insulin resistance, which is mainly present in obesity, could be one of the mechanisms as insulin resistance induces systemic and intraglomerular hypertension (Tucker et al., 1992) as well as mesangial hypertrophy and increased mesangial matrix production (Abrass et al., 1999).

Leptin is a small peptide hormone secreted by adipocytes that regulates food intake. In obese individuals and in patients with impaired renal function, serum leptin levels were increased (Considine et al., 1996). In glomerular endothelial cells, leptin stimulates cellular proliferation and transforming growth factor- $\beta 1$ synthesis (Wolf et al., 1999). Wolf et al. (1999) found out that infusion of leptin in normal rats for 3 weeks resulted in glomerulosclerosis and proteinuria.

The role of inflammation in obesity may be another factor in the development of OAN. It has been reported that C-reactive protein (CRP) levels are elevated with BMI suggesting a state of low-grade systemic inflammation (Visser et al., 1999; Yudkin et al., 1999). Similarly, in 2002, Jong et al. also found that CRP is higher in men and women with elevated BMI compared to individuals with BMI $<25 \mathrm{~kg} / \mathrm{m}^{2}$. 
Obesity leads to glomerular hyperfiltration, increased urinary albumin loss and a progressive loss of renal function, associated with a focal segmental glomerulosclerosis. This is present not only in subjects with renal disease, but also in obese subjects without chronic disease.

\subsection{Dietary Intervention in Renal Disease}

\subsubsection{Fat and Renal Disease Progression}

The effect of different levels and sources of dietary fat have been studied in several types of renal diseases. Reducing the level of dietary fat retards disease progression in animal models of both the CD1-pcy/pcy mouse and the Han:SPRD-cy rats (Lu et al., 1999; Jayapalan et al., 2000). Lu et al. (1999) showed that male CD1-pcy/pcy mice fed a $20 \%$ soybean oil diet for 130 days compared to a $4 \%$ soybean oil diet had higher kidney weight relative to body weight suggesting the potential detrimental effects of high dietary fat. Similarly, in male Han:SPRD-cy rats, consuming a $20 \%$ soybean oil for 6 weeks compared to a $5 \%$ soybean oil resulted in increased kidney weights, kidney water content, cyst scores and serum creatinine, which indicate kidney disease progression and worsened renal function (Jayapalan et al., 2000). These studies show that a low fat diet compared to a high fat diet slows disease progression in animal models of renal cyst disease.

Different fat sources, such as flaxseed, fish oil, and conjugated linoleic acid (CLA), have been studied in several rodent models of renal disease. Flaxseed, a rich source of $n-3$ fatty acids, has been demonstrated to ameliorate the chronic 
interstitial nephritis associated with renal cystic disease in Han:SPRD-cy rats (Ogborn et al., 1999). In this study, flaxseed-fed rats had lower serum creatinine, less cystic change, and less renal fibrosis than controls. In 1990, Yamaguchi et al. reported that fish oil, also containing higher amounts of $n-3$ fatty acids, also slowed early cyst formation in cystic renal disease (Yamaguchi et al., 1990). One previous study from our laboratory showed that long-term feeding of dietary fish oil did not improve survival in pcy mice (Aukema et al., 1992). However, in the Han:SPRD-cy rat, the detrimental effects of a high fat diet in early renal injury were ameliorated by fish oil (Lu et al., 2003). Moreover, 8 weeks of CLA feeding to the same rat model, the Han:SPRD-cy rat, significantly reduced renal inflammation and renal fibrosis (Nitschmann et al., 2001; Ogborn et al., 2003).

In 1991, Kasiske et al. reported that the source of dietary fatty acid consumed altered the fatty acid profile in the kidney of obese fa/fa Zucker rats. After 24 weeks of dietary intervention, 34 week old obese fa/fa Zucker rats fed a $25 \%$ fish oil diet had higher levels of renal $n-3$ fatty acids as reflected by increased eicosapentaenoic acid (EPA) and docosahexaenoic acid (DHA) levels while arachidonic acid $(A A)$ levels were decreased. Obese fa/fa Zucker rats fed $25 \%$ sunflower oil had higher levels of renal $n-6$ fatty acids as reflected by increased linoleic acid while EPA levels were decreased; both the fish oil and sunflower oil groups had reductions in glomerulosclerosis. In 1999, Wheeler et al. reported a similar study using 40 obese fa/fa Zucker rats that had undergone unilateral nephrectomy in order to exacerbate lipid abnormalities and accelerate proteinuria at 10 weeks of age. Rats were divided into three groups. One group 
was given the control diet while the other two groups received a diet supplemented with either $14 \%$ fish oil or $14 \%$ melted beef tallow for 32 weeks. Rats fed fish oil had significantly lower mean plasma cholesterol, triglyceride levels, and less proteinuria than control or beef tallow fed rats. Thus, dietary fat can have a significant effect on progression of kidney disease.

\subsubsection{Protein and Renal Disease Progression}

The role of dietary protein intervention also has been the issue of current research on renal disease progression. It has been demonstrated that both the levels and sources of protein are associated with renal disease progression. Research has shown that high protein diets have a detrimental effect on renal structure and accelerate renal disease progression (Brenner et al., 1982; Ogborn et al., 1995; Tomobe et al., 1994; Williams et al., 1987). In 1982, Brenner et al. discovered that excessive protein intake causes glomerular hyperfiltration, glomerular hypertension, and deterioration of kidney function in the renal ablation model of chronic kidney disease. It has been suggested that individuals who suffer from renal insufficiency should restrict protein intake to lower the kidney work load.

In pcy mice, a diet with $6 \%$ casein compared to $25 \%$ casein resulted in less renal enlargement and lower total cysts (Aukema et al., 1992). In the Han:SPRDcy rat model, a diet with $8 \%$ casein compared to $20 \%$ casein resulted in increased survival time and a reduction in total cyst volume when compared to non-affected animals. Mean serum creatinine and urea levels were significantly 
lower in the low protein fed rats when compared to the $20 \%$ protein fed rats (Ogborn et al., 1995).

Several human studies also have shown similar results. In 1987, Viberti et al. established that low protein diets in healthy humans were associated with lower renal plasma flow, lower GFR, and less albumin excretion. In 1983, Maschio et al. examined the effect of low protein on renal patients ranging from 15 to 68 years of age. This study demonstrated that dietary protein restriction was effective for slowing progression of renal failure in most patients. Similarly, in 1983, Alverstand et al. reported that protein restriction of 15 to $20 \mathrm{~g} /$ day in middle aged patients with renal insufficiency lowered serum creatinine levels. A clinical trial was conducted by the Modification of Diet in Renal Disease Study Group to determine if protein restriction influences the progression of renal disease. This study demonstrated a marginal benefit of protein restriction $(0.58 \mathrm{~g} / \mathrm{kg} /$ day $)$ compared to the typical protein intake $(1.3 \mathrm{~g} / \mathrm{kg} /$ day $)$ in patients suffering from renal insufficiency. In contrast, Klahr et al. (1994) showed no benefit of a very low protein diet $(0.28 \mathrm{~g} / \mathrm{kg} / \mathrm{day})$ in those patients with severe renal disease.

Several meta-analysis have examined the effect of dietary protein restriction on renal function and disease progression have been reported (Kasiske et al., 1998; Pedrini et al., 1996). The results of these studies showed that dietary protein restriction slows the progression of disease in both diabetic and nondiabetic renal diseases.

Studies also have suggested that not only does a low protein diet slow the progression of renal disease but that the type of protein also may play an 
important role. In 1990, Kontessis et al. found that vegetable-based protein diets for 3 weeks had no significant effects on GFR, renal vascular resistance or renal plasma flow in healthy individuals. However, when given animal protein, GFR and renal plasma flow rose and renal vascular resistance fell. One such plantbased protein that has been examined in different models of renal disease is soy protein.

\subsubsection{Dietary Soy Protein and Renal Disease}

Recently, research investigating the role of soy in renal disease and in other chronic diseases has increased dramatically. Especially in the area of chronic kidney disease, a soy based diet appears to attenuate the progression of disease. Soy protein has been recognized as having potential roles in the prevention and treatment of chronic diseases such as cardiovascular disease, cancer, osteoporosis, as well as kidney disease (Messina, 1995).

In 1998, Anderson et al. studied the effects of soy protein on renal function and proteinuria in patients with type $2 \mathrm{DM}$. It was reported that eating $50 \%$ of dietary protein as soy protein for 8 weeks had no distinct effect on renal function or proteinuria in these patients, but it was associated with a significant reduction in serum cholesterol and triglycerides.

In 1987, Williams et al. studied the effects of protein source as well as protein amount using the renal ablation model, an accepted and widely used model of chronic renal disease. Rats were given either a $12 \%$ or $24 \%$ soy protein diet or a $12 \%$ or $24 \%$ casein diet for 12 weeks. Soy protein demonstrated 
beneficial effects on the renal ablated kidney, irrespective of the amount of protein, $12 \%$ or $24 \%$ protein intake. Soy fed rats demonstrated less proteinuria, less hypertrophy, less glomerular sclerosis and a lower mortality rate than casein fed rats. This study indicates that vegetable protein has a less detrimental effect on renal tissue than animal protein.

Subtotally nephrectomized rats given $24 \%$ soy protein-based diets for $10-13$ weeks were shown to have improved survival rate, reduced proteinuria, renal hypertrophy, and renal histological damage compared with rats given $24 \%$ casein diet (Williams et al., 1987). Soy protein feeding in Han:SPRD-cy rats for 6 weeks reduced the number of renal cysts, fibrosis, macrophage infiltration, renal tubular cell proliferation, and apoptosis when compared to a casein based diet (Ogborn et al., 1998). Similar results were also found in the pcy mouse. In this model of renal cyst disease, after 13 weeks of feeding soy protein, animals had lower kidney weights, reduced cyst scores, and less kidney water, indicating a slower progression of disease (Aukema et al., 1999). Long-term feeding of dietary soy protein compared with casein increased life span and decreased renal pathology in Fischer 344 rats (Iwasaki et al., 1988; Shimokawa et al., 1993). In db/db mice, commonly used as a model of type 2 DM, improved glomerular macromolecular permeability and slower development of renal disease were deteced after consuming a either $12 \%$ or $20 \%$ soy protein diet for $21-26$ weeks (Teixeira et al., 2003). Moreover, in rats with chronic nephritic syndrome, soy protein feeding improved renal function and reduced renal damage and inflammatory cytokines (Tovar et al., 2002; Pedraza-Chaverri et al., 2004). In weanling Han:SPRD-cy 
rats given either $20 \%$ soy protein or $20 \%$ casein based diets for 8 weeks, soy fed rats had lower serum creatinine, lower urinary ammonium excretion, reduced renal cysts, renal fibrosis, macrophage infiltration, and renal tubular cell proliferation (Ogborn et al., 1998).

In 1999, Aukema et al. examined the effects of different dietary protein sources and levels on early disease progression in both male and female CD1$p c y / p c y$ mice, a model of renal cyst disease. Ten-week-old CD1-pcy/pcy mice were fed either a soy protein diet or casein diet at a level of $6 \%$ or $17.4 \%$ for 13 weeks. The results with respect to protein sources showed that mice fed the soy protein diet had lower relative kidney weights, lower cyst scores, less kidney water content, and reduced serum urea compared to animals fed casein. With respect to protein levels, dietary protein reduction resulted in lower relative kidney weights, lower cyst scores, less kidney water content, and less serum urea in this rodent model. Therefore, it was concluded both dietary protein source and level significantly affect renal disease progression in CD1-pcy/pcy mice with the effects of dietary soy protein being most pronounced in female animals fed the low protein diet and the effects of protein reduction being most pronounced in animals fed soy protein diet.

Studies from our lab have documented that dietary soy protein compared with casein delays disease progression at the very early stage of renal disease. Soy protein feeding resulted in reduced cyst growth and renal fibrosis as early as 1 to 3 weeks after it was fed to weanling Han:SPRD-cy rats (Fair et al., 2004). Dietary soy protein both in the maternal and post-weaning diet reduced cyst 
growth, cell proliferation, inflammation, and proteinuria (Peng, 2005). These studies demonstrate that early dietary soy protein intervention retards renal disease progression in several models of renal disease.

\subsection{Prostanoids}

\subsubsection{Production of Prostanoids from Cyclooxygenase Enzymes}

The kidney is a rich source of prostanoids which regulate renal hemodynamics, water and solute transport, and renin secretion (Imig, 2000). Altered prostanoid production has been shown in several diseased animal models (Perazella, 2002; Castellani et al., 2003). However, the effects of dietary soy protein on prostanoid production in OAN are not known.

The term, 'eicosanoids', refers to all the oxygenated products synthesized from 20-carbon polyunsaturated fatty acids (PUFAs) (Rahman et al., 1987; Smith and Murphy, 2002). These 20-carbon PUFAs include AA, dihomo-y-linolenic acid (DGLA), and EPA. There are three major pathways leading to eicosanoid production including the cyclooxygenase (COX), lipoxygenase, and epoxygenase pathways (Vane et al., 1998; Williams et al., 1987).

Products of the COX pathway give rise to prostaglandins (PGs) and thromboxanes (TXs) which are collectively termed prostanoids. The lipoxygenase pathway leads to the formation of hydroperoxy eicosatetraenoic acids, hydroxy eicosatetraenoic acids, and leukotrienes. The epoxygenase pathway leads to the formation of epoxyeicosatrienoic acids. While all three pathways are present in 
the kidney, the COX pathway is the major pathway for AA metabolism (Vane et al., 1998) and is the focus of the present study.

Of the 20 carbon fatty acids, there is usually a higher amount of $A A$ in membrane phospholipids compared to either DGLA or EPA. The COX pathway has a higher specificity for AA than for the latter two fatty acids. Under normal circumstances, prostanoids derived from AA seem to be the most important. Series 1 , series 2 , and series 3 prostaglandins are derived from DGLA, AA, and EPA, respectively. Prostanoids derived from EPA tend to oppose or have weaker effects than those derived from AA (Dupont, 1990). The prostanoids coming from DGLA tend to have anti-inflammatory as well as anti-proliferative properties and, therefore, milder biological effects compared to AA derived prostanoids (Fan \& Chapkin, 1998).

There are two isoforms identified, COX-1 and COX-2, both of which are inducible; COX-1 is present in nearly all cell types, while COX-2 is highly expressed in many tissues in response to inflammation (Aukema et al., 2002; Harris, 2000). COX-2 protein expression has been found in the macula densa/cortical thick ascending loop of Henle and medullary interstitial cells in the kidney of mice, rats, rabbits, and dogs (Harris, 2000). Previous studies on COX-2 localization in the human kidney reported expression in podocytes and arteriolar smooth muscle cells and it has also been shown to be expressed in the macula densa and medullary interstitial cells (Komhoff et al., 1997; Komhoff et al., 1999; Nantel et al., 1999). COX-1 gene expression in rat kidney is found in glomerular mesangial cells, distal convoluted tubule, connecting tubule, cortical, and 
medullary collecting ducts, while COX-2 expression is found in glomeruli, cortical thick ascending limb, macula densa, and medullary interstitial cells (Harris, 2000).

Cytosolic phospholipase $2\left(\mathrm{CPLA}_{2}\right)$ releases AA from membrane phospholipids. AA is converted to prostaglandin $\mathrm{H}_{2}$ by COXs, with subsequent conversion to the prostanoids such as prostaglandin $\mathrm{I}_{2}\left(\mathrm{PGI}_{2}\right)$, prostaglandin $\mathrm{E}_{2}$ $\left(\mathrm{PGE}_{2}\right)$, and thromboxane $\mathrm{A}_{2}\left(\mathrm{TXA}_{2}\right)$.

COX is the enzyme that catalyzes the first steps in the production of PGs and TXs from AA. Products of this pathway are denoted by a numerical subscript '2' that represents the number of double bonds. PGs and TXs of this 2 series are the most common prostanoids formed (Smith and Murphy, 2002). Prostanoids containing one double bond are derived from DGLA, therefore, form the ' 1 ' series of eicosanoids. Prostanoids containing three double bonds derived from EPA form ' 3 ' series of eicosanoids.

Prostanoids are not stored by cells, but they are synthesized and released rapidly in response to extracellular hormonal stimuli where they act as local hormones since they are rapidly inactivated in the circulation (Smith and Murphy, 2002). With respect to the kidney, $\mathrm{PGI}_{2}$ and $\mathrm{PGE}_{2}$ are potent vasodilators that increase GFR, while TXA is a potent vasoconstrictor that decreases GFR (Fitzgerald et al., 1987; Harris, 2002; Needleman et al., 1986). 


\subsubsection{Prostanoid Enzymes and Prostanoid Production in Renal Disease}

In 2004, Dey et al. found that the protein expression of COX-1 did not differ in renal microvessels of male lean and obese Zucker diabetic fatty rats (ZDF) at the age of 20-21 weeks, while COX-2 expression was increased in renal microvessels of obese ZDF rats compared to lean rats. This study also reported that urinary excretion of $\mathrm{TXB}_{2}$ and 6-keto $\mathrm{PGF}_{1 \alpha}$ were significantly higher in obese rats, but $P G E_{2}$ was lower in obese rats compared to lean rats. Rofecoxib, a COX-2 inhibitor, was given to the obese rats in their drinking water (10 $\mathrm{mg} / \mathrm{kg} /$ day) for 3 weeks. However, this treatment did not alter urinary excretion of $\mathrm{TXB}_{2}$ or $\mathrm{PGE}$, but it reduced urinary excretion of 6-keto $P G F_{1 a}$ and ameliorated the glomerulosclerosis observed in ZDF rats (Dey et al., 2004). This study, therefore, indicates that COX-2 is involved in renal disease progression in ZDF rats as inhibiting this enzyme ameliorates glomerular injury in this obese rat model.

Similarly, in 2005, Komers et al. also found that COX-2 protein expression was higher in renal cortical tissue of male ZDF rats compared to lean Zucker rats at 4 weeks of age. Moreover, this higher expression of COX-2 became more prominent at 12 weeks of age. However, COX-1 protein expression did not differ between ZDF rats and lean rats at 4 weeks of age, but it was lower in ZDF rats at 12 weeks of age compared to lean rats. In ZDF rats, urinary excretion of $P G E_{2}$ and $\mathrm{TXB}_{2}$ was significantly increased compared to lean rats at 12 weeks. ZDF rats had higher kidney weights at 4 and 12 weeks compared to lean rats. Even though creatinine clearance was not different between ZDF and lean rats, urinary 
weeks. When wortmannin, an insulin-signaling intermediate, was given by intraperitoneal injection ( $100 \mu \mathrm{g} / \mathrm{kg}$ body weight) to additional groups of 12 week old ZDF and lean Zucker rats to examine the role of hyperinsulinemia on renal COX-2, ZDF rats treated with wortmannin had a lower $\mathrm{TXB}_{2}$ excretion compared to vehicle-treated ZDF rats.

In 2005, Xu et al. reported that COX-2 messenger ribonucleic acid (mRNA) and protein expression were higher in the kidney cortex of 23 week old male fa/fa Zucker rats compared to lean control Zucker rats. Treatment with losartan (100 $\mathrm{mg} / \mathrm{L}$ in the drinking water), an angiotensin II type 1 receptor blocker for 4 months attenuated the rise in COX-2 observed in the obese Zucker rats. However, COX1 mRNA expression was not altered in any group of that study.

Studies from our laboratory have demonstrated that enzymes involved in prostanoid metabolism are altered in kidney disease and they seem to be altered in a different manner depending on the types of animal model, the age of the animal, and the specific area of the kidney that is being studied (Aukema et al., 2002; Herchak, 2005; Peng, 2005; Warford, 2003).

In the obese fa/fa Zucker rat, higher protein levels of $\mathrm{CPLA}_{2}$ in cytosolic and particulate fractions and COX-2 in particulate fractions were observed at 14 weeks of age compared to lean Zucker rats (Herchak, 2005; Warford, 2003). Other studies from our lab using a mouse model of polycystic kidney disease indicate that protein expression of $\mathrm{CPLA}$ in both the cytosolic and particulate fractions is higher in diseased male and female mouse kidneys compared to controls at 180 days of age (Aukema et al., 2002). Alterations in the COX 
enzymes in these rodent models of polycystic kidney disease also were detected. COX-1 protein expression is higher in 180 day old male and female diseased mice kidneys and in 70 day old male diseased rat kidneys compared to controls. However, COX-2 protein levels were lower in diseased male rat kidneys compared to controls at 70 days of age (Aukema et al., 2002). These studies suggest that alterations in prostanoid production are important in the pathogenesis of renal disease.

\subsubsection{Prostanoid Production and Dietary Interventions}

Several studies have been carried out in order to determine whether dietary interventions modify renal hemodynamics through effects on renal prostanoids. The purpose of one such study was to determine whether dietary protein intake could exert effects on glomerular prostanoid production in rats with remnant kidneys (Stahl et al., 1987). Rats were placed on either a high protein $(50 \%)$ or a low protein (8.7\%) diet for 2 weeks. Higher proteinuria, GFR, and glomerular $\mathrm{PGE}_{2}, \mathrm{PGI}_{2}$, and $T X \mathrm{~A}_{2}$ production were found in rats on the high protein diet compared to low protein diet.

Another study demonstrated that dietary protein intake modulated glomerular prostanoid production in both normal and diseased rats (Don et al., 1989). Normal and diseased rats were offered either a high protein diet $(40 \%)$ or a low protein diet $(8.5 \%)$ for $10-14$ days. Glomeruli were isolated and incubated in the absence and presence of $A A$, then prostanoid production was measured. In the absence of $A A$, glomerular production of $P G E_{2}$ and $T X A_{2}$ was significantly 
greater in rats on the high protein diet. In the presence of AA, glomerular production of $\mathrm{PGE}_{2}$ and $\mathrm{TXA}_{2}$ also was greater in animals fed the high-protein diet suggesting that glomerular COX activity was augmented. Moreover, enalapril, an angiotensin-converting enzyme inhibitor, was used to investigate the potential role of the renin-angiotensin system in the dietary protein-induced modulation of glomerular prostanoid production in normal rats. Results demonstrated that enalapril attenuated the dietary protein-induced augmentation in glomerular production of $P G E_{2}$ and $T X A_{2}$ and it was concluded that dietary protein modulates glomerular $\mathrm{PGE}_{2}$ and $\mathrm{TXA}_{2}$ synthesis in the rats.

Altering the protein source is also related to alteration in renal hemodynamics, possibly via altering prostanoid production. In one study, healthy individuals were given either an animal protein or a soy protein diet for 3 weeks, and these two diets contained the same amount of total protein (Kontessis et al., 1990). Results showed that protein intake did not differ between groups, but GFR and urinary $\mathrm{PGI}_{2}$ were significantly higher in individuals on the animal protein diet than the soy protein diet. Another study also showed that 1-3 weeks of soy protein feeding compared with casein ameliorated the suppression of $\mathrm{PGE}_{2}$ production in the early stage of renal disease in the Han:SPRD-cy rat model of PKD, (Fair et al., 2004). In the same rat model, but at a later stage of the disease, dietary soy protein lowered the production of $\mathrm{TXA}_{2}$ and $\mathrm{PGI}_{2}$ (Peng, 2005).

The effects of plant protein compared to animal protein based diets on renal prostanoid production may be analogous to the effects of low compared to high 
protein diets, i.e. ameliorating the changes in renal prostanoid production, hyperfiltration and renal disease progression.

\subsection{The Obese fa/fa Zucker Rat}

The obese fa/fa Zucker rat is a model of obesity and the metabolic syndrome. This rat model has a mutation in the leptin receptor resulting in hyperphagia and increased body size. Therefore, this model also develops symptoms of the metabolic syndrome including hypercholesterolemia, hyperinsulinemia, and hypertriglyceridemia observed in human obesity and is sometimes used as a model of pre-diabetes (Bray, 1977; Kasiske et al., 1985; Phillips et al., 1999).

The fa/fa Zucker rat also develops renal disease and ultimately dies of kidney failure. In 1985, Kasiske et al. demonstrated the progression of renal damage and albuminuria, as well as renal functional changes in obese male fa/fa Zucker rats at various ages. By 14 weeks of age, glomerular mesangial matrix expansion was significantly greater in $\mathrm{fa} / \mathrm{fa}$ rats compared to lean rats followed by a rapid increase in albuminuria. By 28 weeks of age, focal glomerulosclerosis was evident and it was extensive at 68 weeks of age in fa/fa rats.

In 2000, Coimbra et al. studied age-related renal changes in male obese $\mathrm{fa} / \mathrm{fa}$ Zucker rats at $6,10,14,18,40$, and 60 weeks of age as well as lean Zucker rats as the controls at 6,14 , and 40 weeks of age. Glomerular hypertrophy was evident in fa/fa rats at 14 weeks of age compared to age-matched lean rats. The width of the glomerular basement membrane was significantly greater in fa/fa rats at 14 weeks of age compared to the lean rats. Hence, investigations 
involving the obese fa/fa Zucker rat would give potential dietary approaches to modulate disease progression in OAN.

\subsection{Hypotheses and Objectives}

Therefore, we propose to use the obese fa/fa Zucker rat, an animal model of obesity to test the following hypotheses:

- Early dietary soy protein feeding will reduce deterioration in renal function and delay glomerular enlargement.

- Early dietary soy protein feeding will alter steady-state protein and mRNA levels of rate-limiting enzymes involved in prostanoid synthesis as well as the production of prostanoid themselves.

To test these hypotheses, 6-week-old obese male fa/fa Zucker rats and lean Zucker rats were given either $17 \%$ soy protein or egg white protein for 8 weeks. The objectives were as follows:

(1) To determine the effect of dietary soy protein on glomeruli size, by staining kidney sections with hemotoxylin and eosin, and to assess proteinuria and creatinine clearance as indicators of renal function.

(2) To determine the effect of dietary soy protein on the steady-state levels of enzymes and gene expression in kidney tissue by western immunoblotting and real time RT-PCR.

(3) To determine the effect of dietary soy protein on renal production of $\mathrm{PGE}_{2}$, 6- keto prostaglandin $F_{1 a}\left(6\right.$-keto $\left.P G F_{1 a}\right)$, stable metabolite of $P G I_{2}$, and 
thromboxane $B_{2}\left(T X B_{2}\right)$, stable metabolite of TXA $A_{2}$ by enzyme immunoassays. 


\section{Dietary Soy Protein Reduces Early Renal Disease Progression and Alters Prostanoid Production in Obese fa/fa Zucker Rats.}

\subsection{Abstract}

Background. With the rising incidence of obesity and the metabolic syndrome, nephropathy associated with obesity also has increased. Soy protein can ameliorate disease in several models of chronic kidney disease. It also may alter the production of renal prostanoids, which play a role in the glomerular hyperfiltration in obesity-associated nephropathy (OAN). Therefore, the effect of dietary soy protein on early disease progression and prostanoid production in OAN was examined in the obese fa/fa Zucker rat.

Methods. Six-week-old male fa/fa and lean Zucker rats were offered complete diets ad libitum containing either $17 \%$ protein from soy protein or egg white protein for 8 weeks. Mean glomerular volume (MGV) and proteinuria were determined to assess early kidney changes and kidney function. Renal prostanoids [thromboxane $\mathrm{B}_{2}\left(\mathrm{TXB}_{2}\right)$, stable metabolite of TXA $;$ 6-keto prostaglandin $F_{1 \alpha}$ (6-keto $P G F_{1 \alpha}$ ), stable metabolite of $\mathrm{PGI}_{2}$; and prostaglandin $E_{2}$ $\left.\left(\mathrm{PGE}_{2}\right)\right]$ were determined by enzyme immunoassay. Renal protein and $\mathrm{mRNA}$ levels of cytosolic phospholipase $A_{2}$ (CPLA $)$, cyclooxygenase-1 (COX-1), and COX-2 were determined by western immunoblotting and QRT-PCR.

Results. Feed consumption, body, and kidney weights were significantly greater in fa/fa compared to lean rats. The fa/fa rats had $43 \%$ larger MGV and $169 \%$ higher proteinuria, reflecting early development of nephropathy. Soy protein feeding did not alter body weights or proteinuria but did result in $6 \%$ lower kidney 
weights ( $\mathrm{g} / 100 \mathrm{~g}$ body weight) and $16 \%$ lower MGV. Prostanoid production in these kidneys was primarily due to COX-2 activity. Renal prostanoids were generally not altered by diet or genotype, however, COX activity as determined by in vitro production of 6-keto $\mathrm{PGF}_{1 \alpha}$ was lower in fa/fa rats given soy compared to egg white protein based diets. Ratios of renal $\mathrm{TXB}_{2} / 6-$ keto $\mathrm{PGF}_{1 \alpha}$ were higher and 6-keto $\mathrm{PGF}_{1 \mathrm{\alpha}} / \mathrm{PGE}_{2}$ ratios were lower, while $\mathrm{TXB}_{2} / \mathrm{PGE}_{2}$ ratios were not different in rats given soy protein compared to egg white protein, also indicating that dietary soy protein reduces renal 6-keto $P G F_{1 a}$ levels.

Conclusion. The attenuation of early nephropathy in fa/fa rats by dietary soy

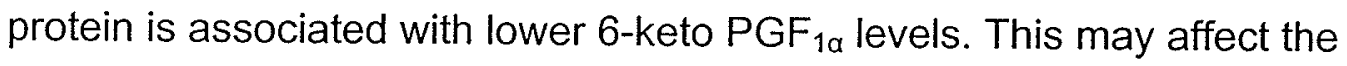
glomerular hyperfiltration observed in OAN.

Key Words: Dietary soy protein; Obesity-associated nephropathy; Cyclooxygenases; and Prostanoids 


\subsection{Introduction}

Obesity has become an international epidemic. Even in children the incidence of obesity is rising with $10 \%$ of children world-wide now being considered obese (Baur, 2006). Obesity is associated with increased risk of a number of disorders including metabolic and cardiovascular diseases such as diabetes and hypertension. While both of these increase the risk for renal disease, obesity itself apart from these disorders also increases risk of renal disease (Srivastava, 2006).

Obesity increases glomerular filtration rate (GFR), apparently by due to dilation of the afferent arteriole while the efferent arteriole is not affected (Jong et al., 2002). Afferent arteriolar dilation leads to increased glomerular capillary pressure causing hyperfiltration, thickening of the glomerular basement membrane, and mesangial expansion that lead to glomerular enlargement. Functionally this early renal disease progression in obesity is also related to increased proteinuria. In the long term, these changes result in fibrosis in both the glomerulus and in the tubulointerstitial tissue (Jong et al., 2002; Phillips et al., 1999; Srivastava, 2006).

Prostanoids are known to be important regulators of renal hemodynamics and may be involved in early kidney changes that ultimately result in obesityassociated nephropathy (OAN). It is known that prostaglandin $\mathrm{I}_{2}\left(\mathrm{PGI}_{2}\right)$ and prostaglandin $E_{2}\left(P E_{2}\right)$ have vasodilatory effects that increase GFR while thromboxane $A_{2}\left(T X A_{2}\right)$ has a vasoconstrictory effect that decreases GFR (Campean et al., 2003; Imig, 2000; Nasrallah et al., 2005; Smith \& Murphy, 2002). 
Individuals who have a $\mathrm{BMI} \geq 25\left(\mathrm{~kg} / \mathrm{m}^{2}\right)$ at age 20 have a 3 -fold increased incidence of kidney failure (Ejerblad et al., 2006). This illustrates the impact of obesity in children on later health and incidence of renal disease. Therefore, early detection and treatment at the very beginning stages of renal disease associated with obesity are important.

Dietary protein level affects the progression of renal diseases, in part via alterations in prostanoid production (Stahl et al., 1987; Yamagisawa et al., 1994; Yamagisawa et al., 1998). The source of dietary protein also can affect disease progression. In this regard, dietary soy protein has been shown to benefit a number of renal diseases. Several of these studies indicate that renal hemodynamics are altered by soy or vegetable protein compared to animal protein sources, possibly by altering prostanoid production (Dhaene et al., 1987; Fair, 2001; Iwasaki et al., 1988; Kontessis et al., 1990; Peng, 2005). Therefore, the effect of dietary soy protein on early disease progression and prostanoid production in OAN was examined in the obese fa/fa Zucker rat.

\subsection{Materials and Methods}

\subsubsection{Animals and Diet}

Twenty lean and 20 obese fa/fa male Zucker rats were purchased from Harlan (Indianapolis, Indiana) at $5 \mathrm{wk}$ of age, acclimated for $1 \mathrm{wk}$ and then randomly divided into four groups in a $2 \times 2$ design. Ten lean and 10 fa/fa rats were given diets (Table 4) containing equal amounts of protein in the form of egg 
Table 4. Diet formulation ${ }^{1}$

\begin{tabular}{|c|c|c|}
\hline $\begin{array}{c}\text { Ingredients }^{2} \\
\text { (g/kg of diet) }\end{array}$ & Control Diet & Soy Protein Diet \\
\hline Cornstarch $^{3}$ & 363.0 & 383.8 \\
\hline Maltodextrin & 132.0 & 132.0 \\
\hline Sucrose & 100.0 & 100.0 \\
\hline Egg white $^{4}$ & 212.5 & 0.00 \\
\hline Soy protein $^{5}$ & 0.00 & 197.7 \\
\hline Mineral Mix $^{\text {Vix }}$ & 35.0 & 35.0 \\
\hline Vitamin Mix $^{\text {Choline }}$ & 10.0 & 10.0 \\
\hline Biotin Mix $^{6}$ & 2.5 & 2.5 \\
\hline Tert-butylhydroquinone $^{7}$ & 10.0 & 10.0 \\
\hline Soy oil & 0.014 & 0.014 \\
\hline
\end{tabular}

${ }^{1}$ Diets were based on the AIN-93G diet.

${ }^{2}$ All ingredients supplied by Harlan Teklad (Madison, Wisconsin) unless otherwise indicated with

${ }^{3}$ Best Foods (Etobicoke, On, Canda)

${ }^{4}$ Egg white contains $80 \%$ protein

${ }^{5}$ Soy protein contains $86 \%$ protein and $3 \mathrm{~g}$ oil/ $100 \mathrm{~g}$ isolate. Thus, less soy oil was added to soy protein diet.

${ }^{6}$ biotin mix $=200 \mathrm{mg}$ biotin $/ \mathrm{kg}$ cornstarch

${ }^{7}$ tert-butylhydroquinone supplied by Aldrich Chemical Company, Milwaukee, WI 
white $(17 \%)$ or soy protein $(17 \%)$ as the control (CTL) or treatment diets, respectively. Body weights were recorded every week and feed intake was recorded three times per week. After $7.5 \mathrm{wk}$ of the experimental diets, the rats were fasted overnight $(12 \mathrm{hr})$ in metabolic cages to obtain urine. At 8 wks, rats were fasted overnight $\left(12 \mathrm{hr}\right.$ ) and killed the following morning by $\mathrm{CO}_{2}$ gas asphyxiation and decapitation. Trunk blood was collected at this time for serum analysis. Serum and urine creatinine were measured colorimetrically using commercial kits (Sigma-Aldrich, Oakville, Canada) and the results were used to calculate creatinine clearance. Urine protein was determined using a colorimetric assay based on the method by Smith et al. (1985). This protein assay is based on the principle that protein will form a mixture with copper II which will then be reduced to copper I. The copper I will form a mixture with bicinchoninic acid (BCA) (Sigma, St. Louis, Missouri) in a concentration dependent manner. All procedures were approved by the University of Manitoba Animal Care Committee and the guidelines of the Canadian Council on Animal Care.

\subsubsection{Glomerular Size}

The right kidney was sliced longitudinally and half of the kidney was placed in $10 \%$ phosphate-buffered formalin prior to embedding in paraffin and sectioning at 5 microns. Kidney sections were placed in xylene to remove the paraffin and stained with hematoxylin and eosin. Using a camera (Spot Diagnostic Instruments, Inc., Sterling Heights, Michigan) mounted on an Olympus BX60 microscope (Olympus Optical Company, Hamburg, Germany), slides were 
analyzed using the $20 \mathrm{X}$ objective. Section images containing at least 1

glomerulus were taken sequentially using the Spot Advanced software program. Thirty glomeruli were then measured using the Image Pro Plus 2 software program. The observer was blinded to treatments for all analyses.

\subsubsection{Immunoblotting}

Steady-state levels of $\mathrm{CPLA}_{2}, \mathrm{COX}-1$, and COX-2 protein expression were determined as described (Aukema et al., 2002). Half of the left kidney was lyophilized and $20 \mathrm{mg}$ was homogenized in 100 volumes of ice-cold homogenization buffer (50 mM Tris-HCL, pH 7.2; 250 mM sucrose; 2 mM EDTA; $1 \mathrm{mM}$ EGTA; $50 \mu \mathrm{M} \mathrm{NaF} ; 100 \mu \mathrm{M}$ Na orthovanadate; $1 \mu \mathrm{g} / \mathrm{ml}$ soybean trypsin inhibitor; $144 \mu \mathrm{M}$ 4-benzene-sulfonyl fluoride; $25 \mu \mathrm{g} / \mathrm{mL}$ aprotonin; $25 \mu \mathrm{g} / \mathrm{mL}$ leupeptin; $25 \mu \mathrm{g} / \mathrm{mL}$ pepstain; and $10 \mathrm{mM} \beta$-mercaptoethanol). Homogenates were centrifuged at $100,000 \times \mathrm{g}$ for 30 minutes at $4^{\circ} \mathrm{C}$ and the supernatant (cytosolic fraction) was removed. The remaining pellet was resuspended in 20 volumes of homogenization buffer containing 1\% Triton X-100 (Sigma, St. Louis, Missouri), incubated on ice for $10 \mathrm{~min}$ and then centrifuged at $100,000 \times \mathrm{g}$ for 30 $\min$ at $4^{\circ} \mathrm{C}$. The resulting supernatant (particulate fraction) was collected. Cytosolic and particulate fractions were subjected to SDS-PAGE as described.

After SDS-PAGE, proteins were transferred to PVDF, blocked, and incubated with primary antibodies to CPLA 2 (Santa Cruz Biotechnology Inc., Santa Cruz, CA), COX-1 and COX-2 (Cayman, Ann Arbor, Michigan) followed by incubation for $1 \mathrm{hr}$ at room temperature with a peroxidase-conjugated secondary 
antibody. Immunoblots were incubated with ChemiGlow ${ }^{\mathrm{TM}}$ (Alpha Innotech, San Leandro, California) and image analysis and quantitation of immunoreactive bands were performed using the Fluorchem ${ }^{\mathrm{TM}} \mathrm{FC}$ digital imaging system (Alpha Innotech Corporation, San Leandro, California).

\subsubsection{Prostanoid Production and COX Activity}

Production of prostanoids and determination of COX isoform activities were analyzed as described (Warford-Woolgar et al., 2006). Briefly, lyophilized left kidneys from each rat were homogenized in fresh Tyrodes buffer and incubated under the following conditions as described: (1) 0 min with no inhibitor for determination of endogenous levels of prostanoid production; (2) $60 \mathrm{~min}$ incubation at $37^{\circ} \mathrm{C}$ with no inhibitor for determination of steady-state in vitro prostanoid production; (3) 10 min incubation at $37^{\circ} \mathrm{C}$ with no inhibitor for determination of total COX activity of prostanoid production; (4) 10 min incubation at $37^{\circ} \mathrm{C}$ with $0.1 \mu \mathrm{M} \mathrm{SC560}$ (Cayman, Ann Arbor, Michigan) for determination of COX-2 activity of prostanoid production. COX-1 activity was determined by the difference between total COX (condition 3) and COX-2 (condition 4) activities.

The incubation conditions were determined from previous time course studies which demonstrated that the production of prostanoids is linear for the first $10 \mathrm{~min}$ of incubation, that steady-state levels of prostanoids are achieved by 30-40 min of incubation, and that a concentration of $0.1 \mu \mathrm{M}$ SC560 inhibits more than $90 \%$ of COX-1 activity but does not inhibit COX-2 at all (Warford-Woolgar et 
al., 2006). Reactions were stopped by adding cold ASA to the sample incubation, vortexing and centrifuging at $12,000 \times \mathrm{g}$ at $4^{\circ} \mathrm{C}$ for $5 \mathrm{~min}$. The supernatant was removed for determination of $\mathrm{PGE}_{2}$ 6-keto $\mathrm{PGF}_{1 \text { a }}$, (stable metabolite of $\mathrm{PGI}_{2}$ ), and $\mathrm{TXB}_{2}$, (stable metabolite of $\mathrm{TXA}_{2}$ ), using commercial enzyme immunoassay kits (Cayman, Ann Arbor, Michigan).

\subsubsection{Quantitative RT-PCR}

Total RNA for real time RT-PCR was extracted from $20 \mathrm{mg}$ of lyophilized kidney. Primers for RT-PCR were chosen using Primer 3 software (Rozen \& Skaletsky, 2003). Oligonucleotide sequences were as follows: sense $\mathrm{CPLA} 2$ primers were 5'-GACTTTTCTGCAAGGCCAAG-3' and antisense 5'-

CTTCAATCCTTCCCGATCAA-3', COX-1 sense were 5'GCCTCGACCACTACCAATGT-3' and antisense 5'AGGTGGCATTCACAAACTCC-3', COX-2 sense were 5'TACCCGGACTGGATTCTACG-3' and antisense 5'TTCGAAGGAAGGGAATGTTG-3'. Real time RT-PCR reactions were performed with SYBR green on a Cepheid Smart Cycler II (Cepheid, Sunnyvale, CA) sequence detection system. Products were verified by melting curve analysis. Relative amounts of mRNA were determined by comparing cycle threshold (CT) values for equal amounts of amplified RNA and calculated using the formula $2^{\Delta C T}$ as described (Warford-Woolgar et al., 2006). 


\subsubsection{Statistical Analysis}

Data were analyzed for normality using the Shapiro-Wilk Statistic and for homogeneity of variance using Levene's Test for Homogeneity of Variance. Data that was not normally distributed was log transformed. A two-way analysis of variance (ANOVA) was used to analyze main [diet (CTL/soy), genotype (lean/fa/fa)] effects and interactions. If interactions were present $(P<0.05)$ or when the $P$-value of main effects were marginal $(0.05<P<0.10)$, least significant difference (LSD) tests were performed to test for differences among groups. Data were analyzed using SAS (SAS Institute, version 9.1, Cary, North Carolina).

\subsection{Results}

At the end of the feeding period, fa/fa rats had consumed approximately $50 \%$ more diet and were significantly larger than lean rats (Table 5). Rats grew equally well on both diets, despite the slightly lower feed intake (7\%) in fa/fa rats

given the soy based compared to the CTL diet. The fa/fa rats had larger kidneys than lean rats at the end of the study on a weight basis, but relative to body weights, the kidney weights in fa/fa rats were smaller than in lean rats. There was a significant effect of dietary soy protein with rats given soy protein having lower kidney weights relative to body weights compared to CTL diets. 
Table 5. Effects of dietary soy protein on feed intake, body and kidney weights, proteinuria, and creatinine clearance in obese fa/fa Zucker rats. Values are mean \pm SEM. Different letters in rows are significantly different, $P$ $<0.05$.

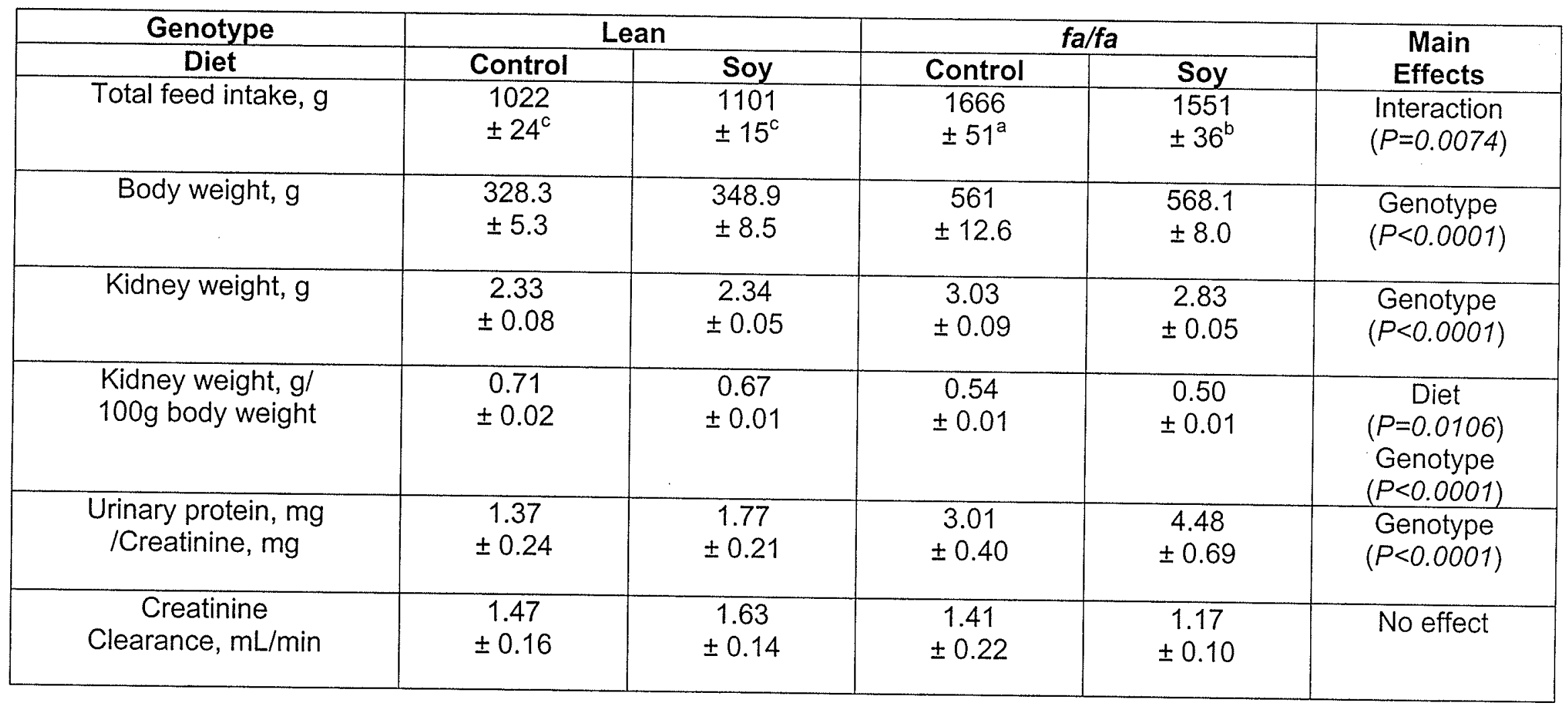


One of the earliest signs of OAN is an increase in glomerular size. Glomerular size was elevated in $\mathrm{fa} / \mathrm{fa}$ rats as indicated by the $43 \%$ larger mean glomerular volume (MGV) in these rats compared to lean rats (Figure 1 and 2). This increased size was mitigated by soy protein feeding which resulted in $16 \%$ lower MGVs compared to the CTL fed rats. These early kidney changes . reflecting renal damage in fa/fa rats were reflected in the increased proteinuria in these rats, but serum creatinine and creatinine clearance were not altered in this early stage of OAN (Appendix 7.5). The dietary protein source did not influence these markers of renal function.

To determine the potential role of prostanoids in these effects, prostanoid levels and COX activities were determined. These analyses determined that renal COX activity was due primarily to the COX-2 isoform as can be seen in the similar levels of total COX and COX-2 activities (Tables 6-9). Renal prostanoid levels and COX activities were generally not altered by diet or genotype. However, renal 6-keto $\mathrm{PGF}_{1 \mathrm{a}}$ levels produced by COX activity were lower in fa/fa rats fed soy protein, which suggested that dietary soy protein reduces 6-keto $\mathrm{PGF}_{1 \alpha}$ production as result of COX activity.

In order to probe further the possible effects of dietary soy protein on 6-keto $\mathrm{PGF}_{1 \mathrm{a}}$, ratios were calculated and compared to determine whether there were changes in individual prostanoids relative to others. Renal $T X_{2} / 6-k e t o P G F_{1 \alpha}$ ratios were significantly higher in the kidneys from rats given soy protein 
Figure 1. Effects of dietary soy protein on mean glomerular volume (MGV). Values are mean \pm SEM $(n=10 / \text { group, except } n=9 \text { for } \ln \text { SOY })^{1}$.

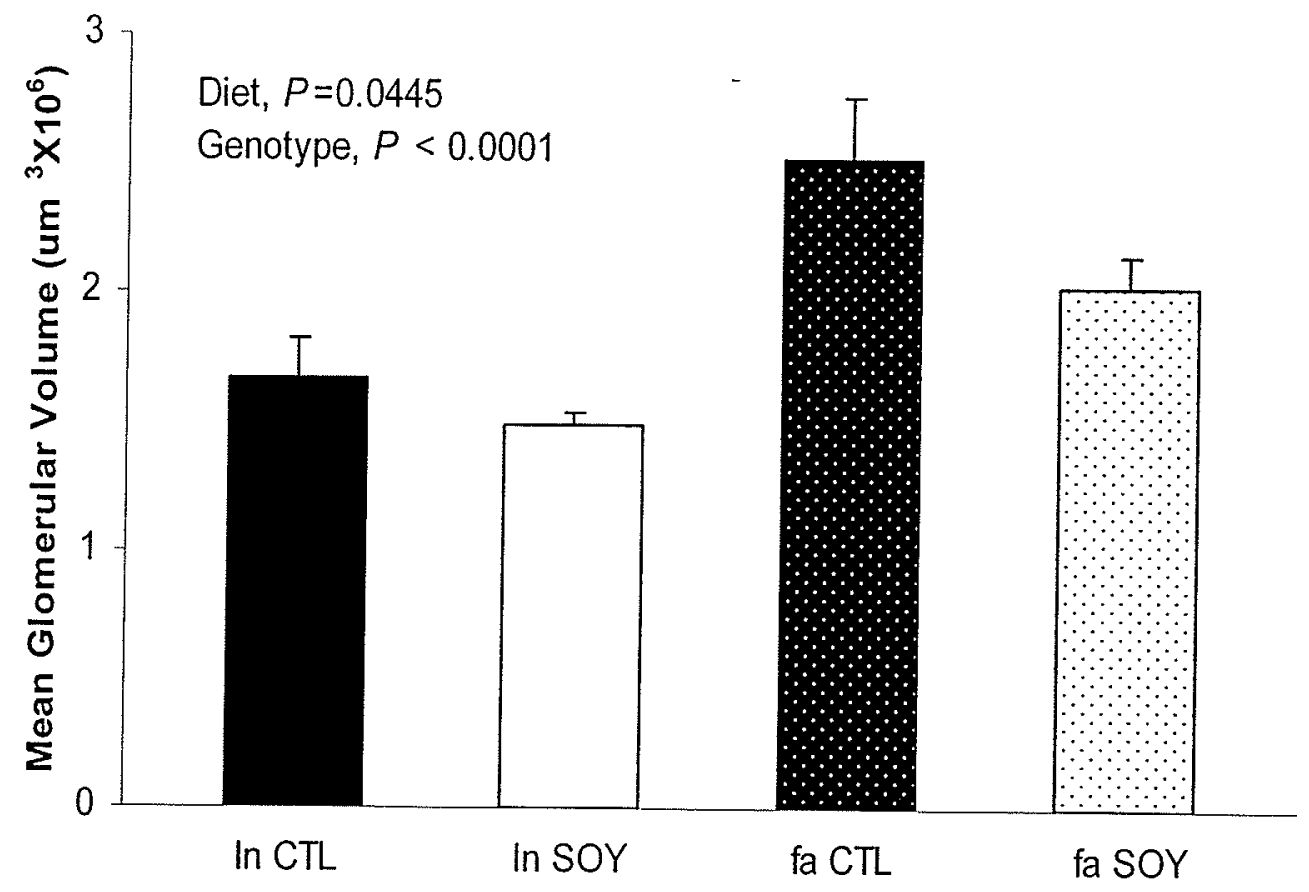

${ }^{1}$ Abbreviations: In CTL, lean rats fed control diet; In SOY, lean rats fed soy protein diet; fa CTL, fa/fa rats fed control diet; and fa SOY, fa/fa rats fed soy protein diet 
Figure 2. Kidney cross sections stained with eosin and hematoxylin ${ }^{1}$. (Arrows point to glomeruli.)
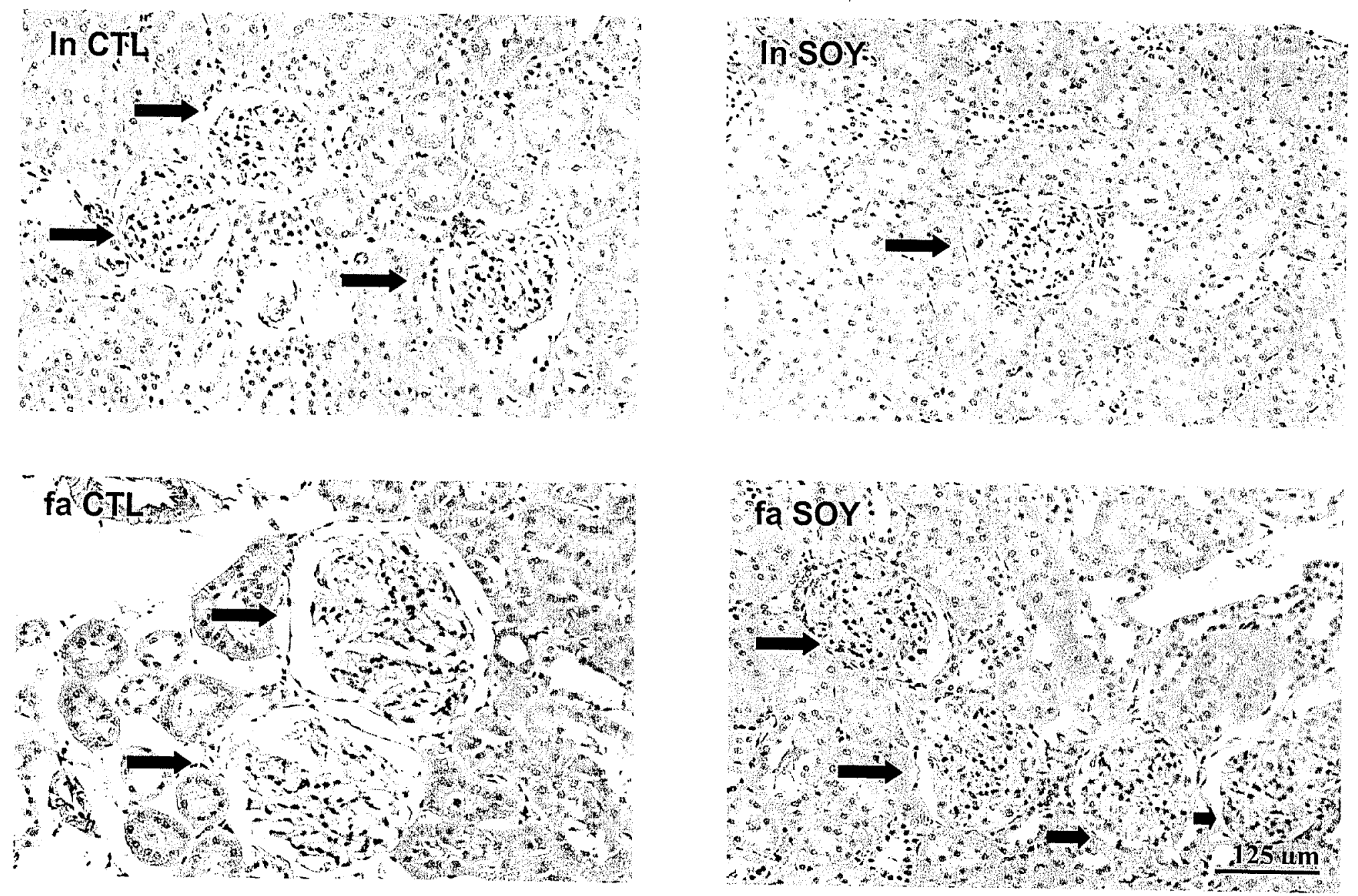

${ }^{1}$ Abbreviations: In CTL, lean rats fed control diet; In SOY, lean rats fed soy protein diet; fa CTL, fa/fa rats fed control diet; and fa SOY, fa/fa rats fed soy protein diet 
Table 6. Effects of dietary soy protein on endogenous prostanoid levels ( $\mathrm{ng} / \mathrm{mg}$ protein) in kidneys of obese fa/fa Zucker rats. Values are mean \pm SEM ( $n=9$-10/group).

\begin{tabular}{|c|c|c|c|c|c|}
\hline Genotype & \multicolumn{2}{|c|}{ Lean } & \multicolumn{2}{|c|}{$f a / f a$} & \multirow[t]{2}{*}{ Main Effects } \\
\hline Diet & Control & Soy & Control & Soy & \\
\hline $\mathrm{TXB}_{2}$ & $\begin{array}{c}0.15 \\
\pm 0.02\end{array}$ & $\begin{array}{c}0.16 \\
\pm 0.02\end{array}$ & $\begin{array}{c}0.14 \\
\pm 0.02\end{array}$ & $\begin{array}{c}0.14 \\
\pm 0.02\end{array}$ & No effect \\
\hline $\mathrm{PGE}_{2}$ & $\begin{array}{c}1.07 \\
\pm 0.20\end{array}$ & $\begin{array}{r}1.07 \\
\pm 0.19\end{array}$ & $\begin{array}{c}0.58 \\
\pm 0.08\end{array}$ & $\begin{array}{c}0.71 \\
\pm 0.10\end{array}$ & $\begin{array}{c}\text { Genotype } \\
(P=0.0068)\end{array}$ \\
\hline 6-keto PGF $1 a$ & $\begin{array}{c}1.86 \\
\pm 0.26\end{array}$ & $\begin{array}{c}1.77 \\
\pm 0.28\end{array}$ & $\begin{array}{c}1.77 \\
\pm 0.28\end{array}$ & $\begin{array}{c}1.18 \\
\pm 0.14\end{array}$ & No effect \\
\hline Total & $\begin{array}{c}3.01 \\
\pm 0.44\end{array}$ & $\begin{array}{c}2.90 \\
\pm 0.46\end{array}$ & $\begin{array}{c}2.18 \\
\pm 0.32\end{array}$ & $\begin{array}{c}2.00 \\
\pm 0.26\end{array}$ & $\begin{array}{c}\text { Genotype } \\
(P=0.0368)\end{array}$ \\
\hline
\end{tabular}


Table 7. Effects of dietary soy protein on in vitro steady-state prostanoid levels ( $\mathrm{ng} / \mathrm{mg}$ protein) in kidneys of obese fa/fa Zucker rats. Values are mean \pm SEM ( $n=9-10 /$ group).

\begin{tabular}{|c|c|c|c|c|c|}
\hline Genotype & \multicolumn{2}{|c|}{ Lean } & \multicolumn{2}{c|}{ Main Effects } \\
\hline Diet & Control & Soy & Control & Soy & \\
\hline TXB $_{2}$ & 0.16 & 0.18 & 0.24 & 0.21 & No effect \\
& \pm 0.02 & \pm 0.03 & \pm 0.04 & \pm 0.03 & \\
& & & & & \\
\hline PGE $_{2}$ & 2.97 & 3.31 & 2.72 & No effect \\
& \pm 0.34 & \pm 0.54 & \pm 0.45 & \pm 0.40 & \\
& & & & & No effect \\
& 13.97 & 15.37 & 20.86 & 13.98 & \\
\hline 6-keto PGF 1 1a & \pm 1.65 & \pm 2.96 & \pm 3.54 & \pm 1.70 & No effect \\
& & & & & \\
\hline Total & 17.00 & 18.69 & 20.18 & 17.13 & \\
& \pm 1.89 & \pm 3.50 & \pm 2.07 & & \\
\hline
\end{tabular}


Table 8. Effects of dietary soy protein on total COX activity ( $\mathrm{ng} / \mathrm{min} / \mathrm{mg}$ protein) in kidneys of obese fa/fa Zucker rats. Values are mean \pm SEM ( $n=9-10 /$ group).

\begin{tabular}{|c|c|c|c|c|c|}
\hline Genotype & \multicolumn{2}{|c|}{ Lean } & \multicolumn{2}{|c|}{$f a / f a$} & \multirow[t]{2}{*}{ Main Effects } \\
\hline Diet & Control & Soy & Control & Soy & \\
\hline $\mathrm{TXB}_{2}$ & $\begin{array}{c}0.01 \\
\pm 0.00\end{array}$ & $\begin{array}{c}0.01 \\
\pm 0.00\end{array}$ & $\begin{array}{c}0.02 \\
\pm 0.00\end{array}$ & $\begin{array}{c}0.02 \\
\pm 0.00\end{array}$ & No effect \\
\hline $\mathrm{PGE}_{2}$ & $\begin{array}{c}0.20 \\
\pm 0.02\end{array}$ & $\begin{array}{c}0.25 \\
\pm 0.05\end{array}$ & $\begin{array}{c}0.22 \\
\pm 0.04\end{array}$ & $\begin{array}{c}0.24 \\
\pm 0.04\end{array}$ & No effect \\
\hline 6-keto PGF $_{1 \alpha}$ & $\begin{array}{c}0.86 \\
\pm 0.14 \text { ac }\end{array}$ & $\begin{aligned} & 0.83 \\
\pm & 0.17 \text { bc }\end{aligned}$ & $\begin{array}{r}1.24 \\
\pm 0.2^{\mathrm{a}}\end{array}$ & $\begin{aligned} & 0.77 \\
\pm & 0.10 \mathrm{bc}\end{aligned}$ & $\begin{array}{c}\text { Diet } \\
(P=0.0628)\end{array}$ \\
\hline Total & $\begin{array}{c}1.07 \\
\pm 0.15\end{array}$ & $\begin{array}{c}1.08 \\
\pm 0.22\end{array}$ & $\begin{array}{c}1.27 \\
\pm 0.16\end{array}$ & $\begin{array}{c}1.01 \\
\pm 0.15\end{array}$ & No effect \\
\hline
\end{tabular}


Table 9. Effects of dietary soy protein on COX-2 activity ( $\mathrm{ng} / \mathrm{min} / \mathrm{mg}$ protein) in kidneys of obese fa/fa Zucker rats. Values are mean \pm SEM $(n=9-10$ /group).

\begin{tabular}{|c|c|c|c|c|c|}
\hline Genotype & \multicolumn{2}{|c|}{ Lean } & \multicolumn{2}{|c|}{$\mathrm{fa} / \mathrm{fa}$} & \multirow[t]{2}{*}{ Main Effects } \\
\hline Diet & Control & Soy & Control & Soy & \\
\hline $\mathrm{TXB}_{2}$ & $\begin{array}{c}0.01 \\
\pm 0.00\end{array}$ & $\begin{array}{c}0.01 \\
\pm 0.00\end{array}$ & $\begin{array}{c}0.02 \\
\pm 0.00\end{array}$ & $\begin{array}{c}0.02 \\
\pm 0.00\end{array}$ & No effect \\
\hline $\mathrm{PGE}_{2}$ & $\begin{array}{c}0.19 \\
\pm 0.02\end{array}$ & $\begin{array}{c}0.24 \\
\pm 0.04\end{array}$ & $\begin{array}{c}0.22 \\
\pm 0.04\end{array}$ & $\begin{array}{c}0.21 \\
\pm 0.03\end{array}$ & No effect \\
\hline 6-keto $\mathrm{PGF}_{1 \alpha}$ & $\begin{array}{c}0.86 \\
\pm 0.13\end{array}$ & $\begin{array}{c}0.88 \\
\pm 0.15\end{array}$ & $\begin{array}{c}1.17 \\
\pm 0.16\end{array}$ & $\begin{array}{c}0.88 \\
\pm 0.11\end{array}$ & No effect \\
\hline Total & $\begin{array}{c}1.07 \\
\pm 0.15\end{array}$ & $\begin{array}{c}1.12 \\
\pm 0.19\end{array}$ & $\begin{array}{c}1.25 \\
\pm 0.16\end{array}$ & $\begin{array}{c}1.10 \\
\pm 0.13\end{array}$ & No effect \\
\hline
\end{tabular}


compared to CTL diets indicating that dietary soy protein reduced either 6-keto $P F_{1 a}$ and/or increased $\mathrm{TXB}_{2}$ (Figure 3). Similarly, 6-keto $P G F_{1 \alpha} / P E_{2}$ ratios were lower in soy protein fed rats compared to the CTL diet, indicating that dietary soy protein either reduced renal 6-ketoPGF $F_{1 a}$ levels and/or increased $\mathrm{PGE}_{2}$ (Figure 4). Renal $\mathrm{TXB}_{2} / \mathrm{PGE}_{2}$ ratios, on the other hand, were not different (Figure 5). It is not likely that these prostanoid levels are altered, as the individual prostanoid measurements do not support that interpretation. Therefore, taken together, these results suggest that 6 -keto $P G F_{1 \alpha}$ is reduced while $P G E_{2}$ and $\mathrm{TXB}_{2}$ are not altered.

COX-2 protein and mRNA expression were elevated in kidneys from fa/fa compared to lean rats, as determined by western immunoblotting (Figure 6) and QRT-PCR (Figure 7). Dietary soy protein did not alter the expression of COX-2 protein, though gene expression was altered by diet. The COX isoforms were present only in the particulate fraction, while $\mathrm{CPLA}_{2}$ was present in both the cytosolic and particulate fractions. Neither COX-1 nor $\mathrm{CPLA}_{2}$ levels were altered by genotype or diet. 
Figure 3. Effects of dietary soy protein on $\mathrm{TXB}_{2} / 6$-keto $P G F_{1 \alpha}$ ratio in kidneys of obese fa/fa Zucker rats in the following conditions: 0-min incubation (endogenous levels), 60-min incubation (in vitro steady-state levels), COX activity, and COX-2 activity. Values are mean \pm SEM ( $n=8-10 /$ group $)^{1}$.

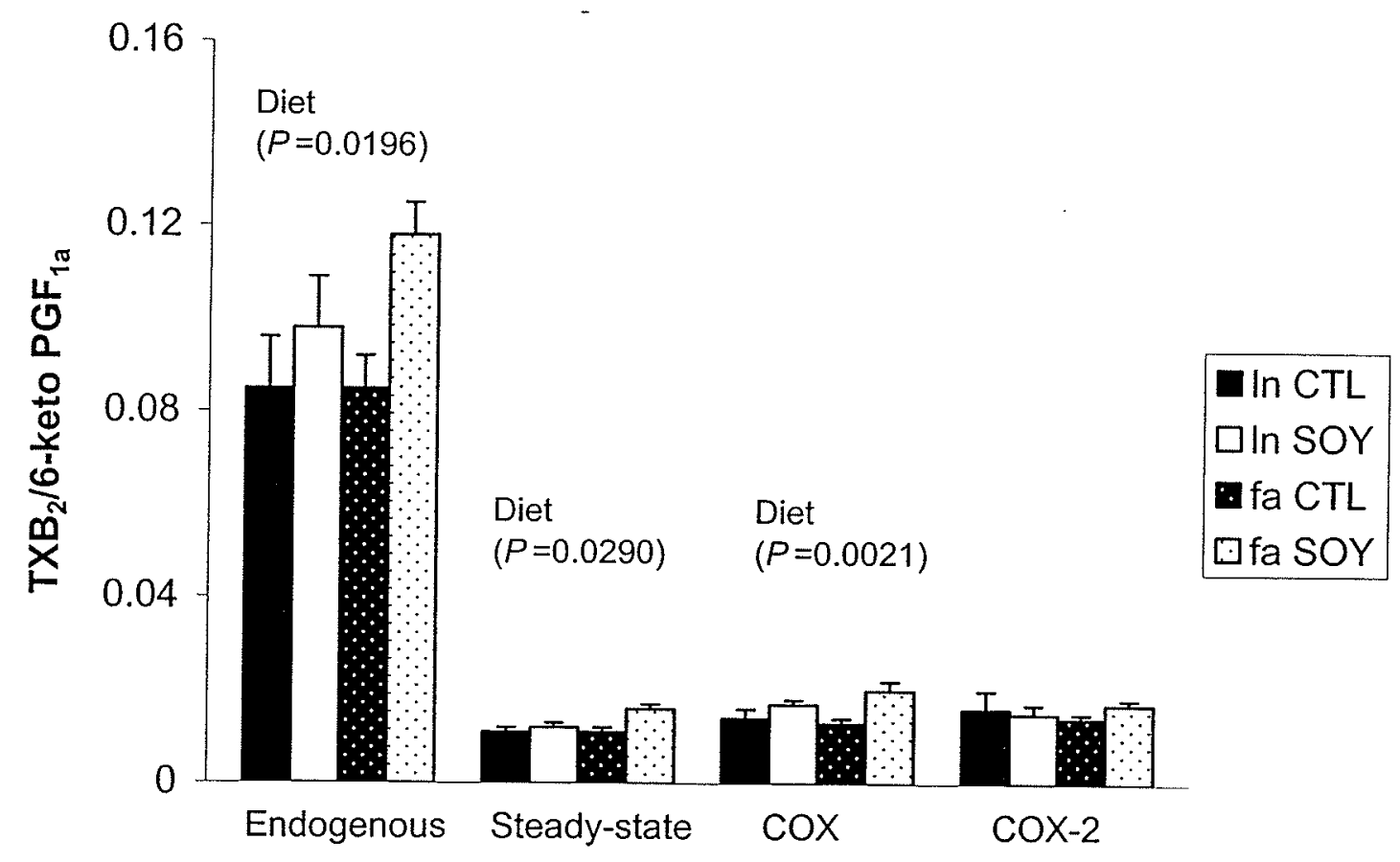

${ }^{1}$ Abbreviations: COX, cyclooxygenase; COX-2, cyclooxygenase-2; In CTL, lean rats fed control diet; In SOY, lean rats fed soy protein diet; fa CTL, fa/fa rats fed control diet; and fa SOY, fa/fa rats fed soy protein diet 
Figure 4. Effects of dietary soy protein on 6-keto $\mathrm{PGF}_{1 \mathrm{a}} / \mathrm{PGE}_{2}$ ratio in kidneys of obese fa/fa Zucker rats in the following conditions: 0-min incubation (endogenous levels), 60-min incubation (in vitro steady-state levels), COX activity, and COX-2 activity. Values are mean \pm SEM $(n=8-10 / \text { group })^{1}$. Different letters in columns are significantly different, $P<0.05$.

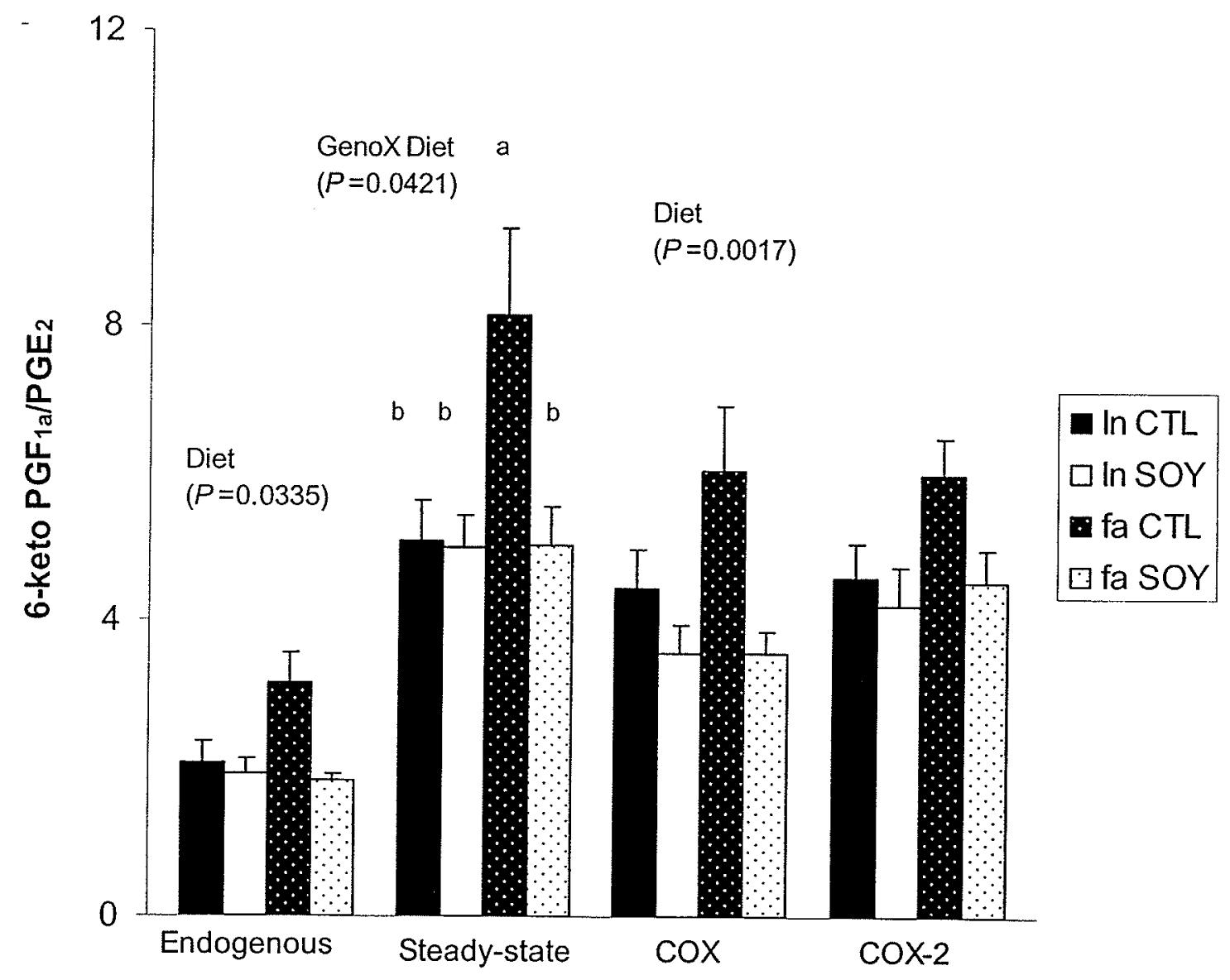

\footnotetext{
${ }^{1}$ Abbreviations: COX, cyclooxygenase; COX-2, cyclooxygenase-2; In CTL, lean rats fed control diet; In SOY, lean rats fed soy protein diet; fa CTL, fa/fa rats fed control diet; and fa SOY, fa/fa rats fed soy protein diet
} 
Figure 5. Effects of dietary soy protein on $\mathrm{TXB}_{2} / \mathrm{PGE}_{2}$ ratio in kidneys of obese $\mathrm{fa} / \mathrm{fa}$ Zucker rats in the following conditions: 0-min incubation (endogenous levels), 60-min incubation (in vitro steady-state levels), COX activity, and COX-2 activity. Values are mean \pm SEM ( $n=8-10$ /group) ${ }^{1}$.

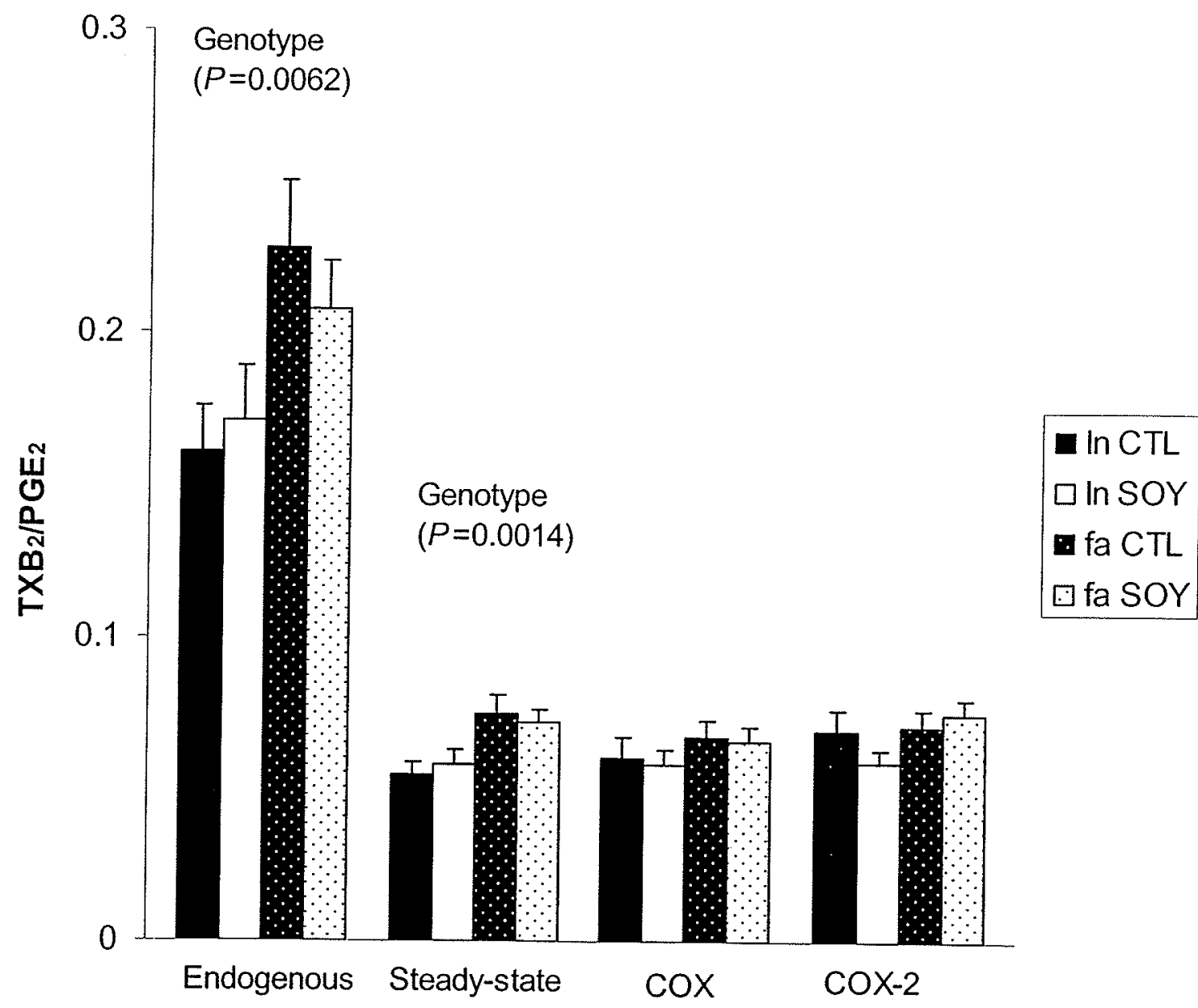

${ }^{1}$ Abbreviations: COX, cyclooxygenase; COX-2, cyclooxygenase-2; In CTL, lean rats fed control diet; In SOY, lean rats fed soy protein diet; fa CTL, fa/fa rats fed control diet; and fa SOY, fa/fa rats fed soy protein diet 
Figure 6. Effects of dietary soy protein on relative cytosolic $\mathrm{CPLA}$, particulate $\mathrm{CPLA}_{2}, \mathrm{COX}-1$, and COX-2 protein expression ${ }^{1}$. Data are expressed relative to In CTL group and as mean \pm SEM ( $n=8-10 /$ group).

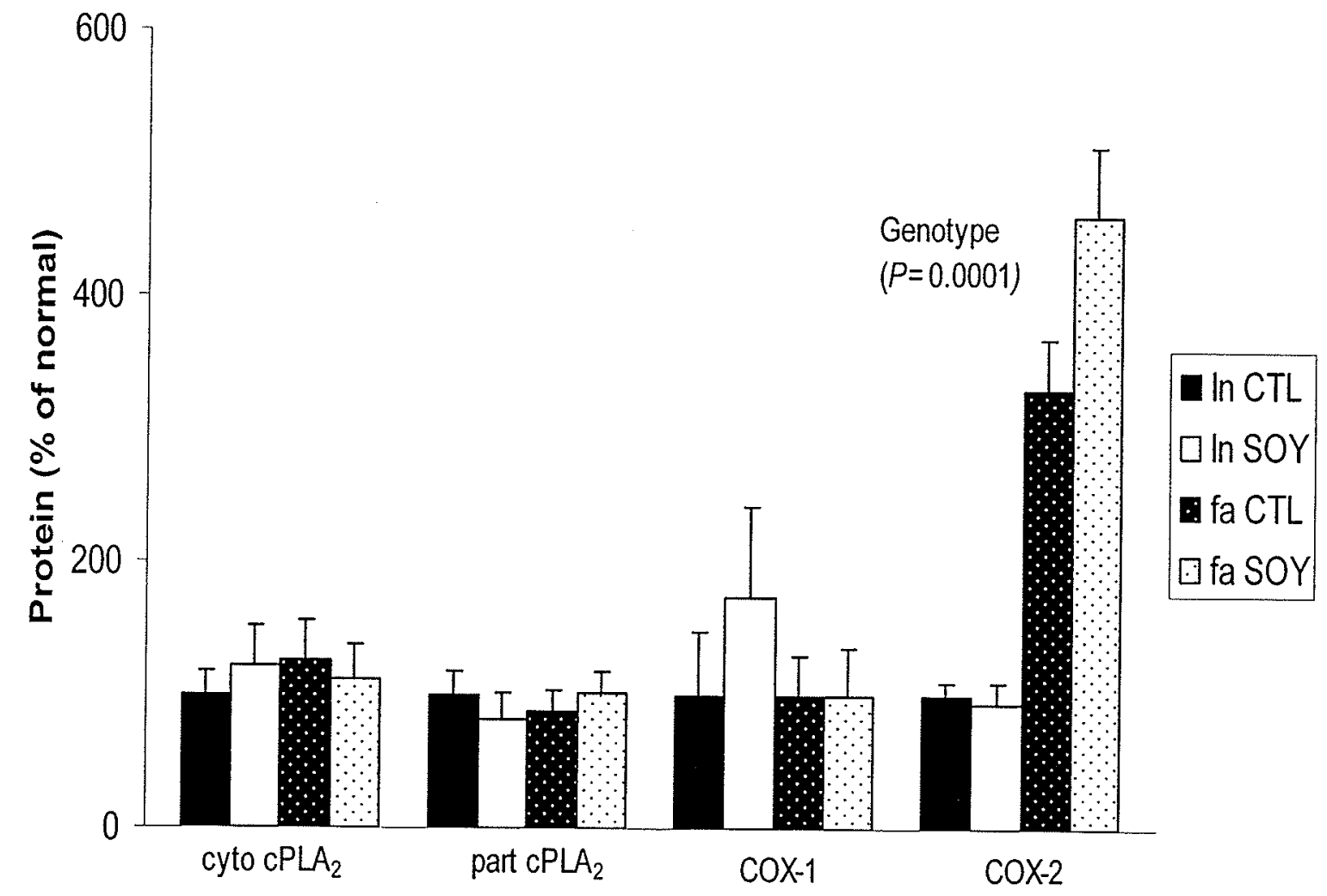

${ }^{1}$ Abbreviations: cyto $\mathrm{CPLA}$, cytosolic fraction of cytosolic phospholipase $\mathrm{A}_{2}$; part $c P L A_{2}$, particulate fraction of cytosolic phophlipase $A_{2}$ : COX-1, cyclooxygenase-1; COX-2, cyclooxygenase-2; in CTL, lean rats fed control diet; In SOY, lean rats fed soy protein diet; fa CTL, fa/fa rats fed control diet; and fa SOY, fa/fa rats fed soy protein diet 
Figure 7. Effects of dietary soy protein on relative $\mathrm{CPLA}_{2}, \mathrm{COX}-1$, and $\mathrm{COX}-2$ mRNA expression. Data are expressed relative to In CTL group and as mean \pm SEM ( $n=8-10$ /group $^{1}$. Different letters in columns are significantly different, $P<$ 0.05 .

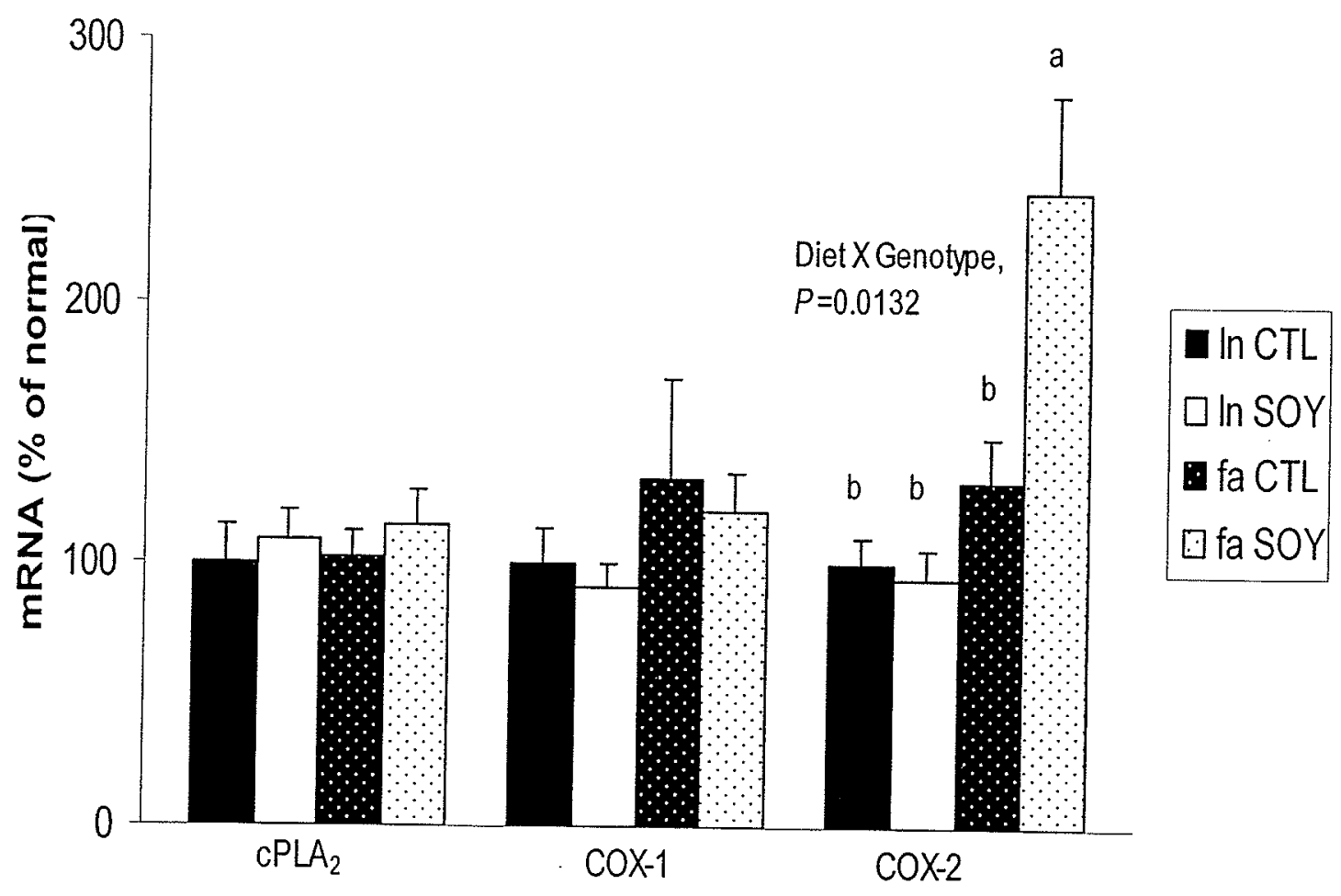

${ }^{1}$ Abbreviations: $\mathrm{CPLA}_{2}$, cytosolic phophlipase $\mathrm{A}_{2}$ : COX-1, cyclooxygenase-1; COX-2, cyclooxygenase-2; In CTL, lean rats fed control diet; In SOY, lean rats fed soy protein diet; fa CTL, fa/fa rats fed control diet; and fa SOY, fa/fa rats fed soy protein diet 


\subsection{Discussion}

This study confirms the beneficial effect of dietary soy protein intervention on early renal disease progression associated with obesity in the obese fa/fa Zucker rat. The soy protein diet provides protection against the progression of glomerular injury, as demonstrated by reduced MGV.

Glomerular hypertrophy is one of the earliest sign of kidney disease and has been proposed as an independent risk factor for the progression of renal disease. The beneficial effect of soy protein on glomerular size observed herein in $14 \mathrm{wk}$ old rats is consistent with previous observation in 24 wk obese fa/fa Zucker rats (Maddox et al., 2002). One difference between the previous study and the present study is the rats from the previous study were older, therefore, and kidney disease was already established. Another difference is the previous study used casein as an animal protein source versus soy protein. In this current study we used egg white protein which is a high quality animal protein. The lack of significant effects on renal function is likely due to the very early stage of renal disease in the 14 wk Zucker rat.

OAN is characterized by glomerular hyperfiltration, increased glomerular pressure and size, and subsequent development of fibrosis (Jong et al., 2002). The current findings suggest that the effect of dietary soy protein on renal 6-keto PGF $_{1 a}$ may be a mechanism by which soy protein mediates its beneficial effect on glomerular size.

How these prostanoids are influenced by soy protein may be analogous to the effects of high protein diets that have been shown to alter prostaglandins in 
kidneys and lead to hyperfiltration. Low compared to high protein diets ameliorate these changes in prostaglandin production and hyperfiltration and renal disease progression (Stahl et al., 1987; Yamagisawa et al., 1994; Yamagisawa et al., 1998).

Altering the protein source is another approach that has been used in treating renal disease. It is known that plant compared to animal proteins alter renal hemodynamics (Dhaene et al., 1987; Iwasaki et al., 1988; Kontessis et al., 1990). One such protein source that has been studied in several models of renal disease is soy protein. Studies from our laboratory have demonstrated that soy protein can alter prostanoid production in rats with renal cyst disease (Fair et al., 2004; Peng, 2005). In this present study, dietary soy protein reduces the production of 6-keto $\mathrm{PGF}_{1 \alpha}$. The reduction in 6-keto $\mathrm{PGF}_{1 \alpha}$ production would reduce the dilation of the afferent arteriole and the glomerular capillary pressure which causes glomerular hyperfiltration.

Our previous study showed that dietary soy protein attenuated the higher protein levels of particulate $\mathrm{CPLA}_{2}$ in the Han:SPRD-cy rat, a rat model of polycystic kidney disease (Peng, 2005). In another study, COX-2 protein expression was significantly reduced in the obese fa/fa Zucker rat, the same rat model as in this current study, when given dietary conjugated linoleic acid (CLA) (Herchak, 2005). In the present study, there were no significant diet or genotype effects for $\mathrm{CPLA}_{2}$ protein and mRNA expression. In contrast, COX-2 protein expression was elevated in fa/fa rats, and this result is consistent with our previous studies and others (Dey et al., 2004; Herchak et al., 2005; Komers et al., 
2005; Warford, 2003; Xu et al., 2005). Higher levels of this enzyme appear to be related to renal disease progression. In addition, $\mathrm{Xu}$ et al. show higher COX-2 protein and mRNA expression in the kidney cortex of fa/fa Zucker rats compared to lean rats (Xu et al., 2005). Interestingly, while there was no significant dietary effect on protein expression, in this present study COX-2 mRNA expression in kidneys from fa/fa rats given soy protein was elevated compared to CTL diet. There were no significant effects for COX-1 protein and mRNA expression in this current study, which agrees with the results of our previous studies in the same rat model (Herchak, 2005; Warford, 2003).

In conclusion, the present study indicates that dietary soy protein attenuates early renal development of nephropathy in the obese fa/fa Zucker rats. These effects are associated with lower 6-keto PGF 1 levels. With obesity, glomerular size increases due to dilation of the afferent arteriole. In this present study, when soy protein is given in the diet, the reduction in 6-keto $\mathrm{PGF}_{1 \alpha}$ production would reduce this dilation and the glomerular capillary pressure. The prevalence of the metabolic syndrome in U.S. is greater than 47 million with the rising incidence of obesity (Abrass, 2004; Bagby, 2004; Tuttle, 2005). An aspect of metabolic syndrome associated with chronic renal disease suggests that people with obesity are at increased risk for progressive loss of renal function. More importantly, obesity is not only a problem for the adult but is becoming a concern for the young population (Csernus et al., 2005). Hence, an early intervention strategy is important to prevent and/or slow early OAN. 


\section{Overall Discussion}

The epidemic of obesity in adult, as well as in both boys and girls, is rapidly increasing throughout the world. This trend mirrors a concurrent rise in the prevalence of related chronic diseases including kidney disease internationally (Lobstein et al., 2004). In addition, obesity worsens disease in individuals with underlying kidney disease.

Some strategies to slow renal disease progression include treatment of blood pressure using angiotensin-converting enzyme inhibitors and angiotensin receptor blockers and dietary intervention (Hostetter, 2003). Early studies showed that dietary protein restriction modified the course of progressive renal disease (Brenner et al., 1982; Kasiske et al., 1998; Klahr \& Purkerson, 1998; Williams et al., 1987; Zeller et al., 1991). However, the use of dietary protein restriction is controversial because of the risk of protein malnutrition and the difficulty of maintaining this diet in the long-term. Altering the source of protein may be beneficial in delaying renal disease progression.

Previous studies report that consumption of plant-derived proteins such as soy protein retards the progress of renal disease in several animal models and, in humans improves renal function and reduces renal damage (Anderson et al., 1998; Maddox et al., 2002; Ogborn et al., 1998; Teixeira et al., 2003; Tovar et al., 2002; Trugillo et al., 2005; Williams et al., 1987). In addition, recent studies show that soy protein delays progression of renal disease in the early stages, again suggesting the beneficial effects of soy protein (Fair et al., 2004; Peng, 2005). 
Kidneys are a relatively rich source of prostanoids, which are important regulators of kidney physiology in health and in disease. In normal kidneys prostanoids regulate renal processes such as hemodynamics, water and solute transport and renin secretion. Prostanoids in diseased kidneys play a role maintaining glomerular filtration rate (GFR) as well as being involved in proliferative and inflammatory processes in response to renal injury.

The present study demonstrates the effects of dietary soy protein intervention on early renal disease progression in obesity. Rats given soy had lower kidney weights ( $\mathrm{g} / 100 \mathrm{~g}$ body weight) and lower MGV compared to rats fed the CTL diet. Feed consumption, body weights, and kidney weights were significantly greater in fa/fa compared to lean rats. Since the fa/fa rat model is hyperphagic, a greater total feed intake is to be expected. The hyperphagia observed in this rat model is a result of an inactivating mutation in the leptin receptor gene. Leptin is a hormone responsible for maintaining a balance between energy expenditure and food intake (Bray et al., 1977). Since leptin does not function properly in this rat model, fa/fa rats are unable to suppress their appetites. In this study, fa/fa rats fed soy protein had a $41 \%$ greater feed intake than lean rats fed soy. In addition, fa/fa rats fed CTL had a $63 \%$ greater feed intake compared to lean rats fed CTL. However, fa/fa rats fed soy protein had a $7 \%$ smaller feed intake compared to fa/fa rats fed CTL.

The fa/fa rats, as their name implies, were $67 \%$ heavier than lean rats. However, the final body weight was not significantly altered by diet. This raises the question of why a reduced feed intake did not lead to a reduced body weight. 
It might be because the obese fa/fa Zucker rats are more efficient in converting their feed to weight gain than lean rats, as reported by Sisk et al. (2001). In their study, $0.5 \%$ dietary CLA reduced adiposity in the lean rats but not the fa/fa rats. Bray et al. also reported that pair feeding of fa/fa Zucker rats to the feed intake of lean rats did not lead to the normalization of body fat content nor to the elimination of the characteristic defects of these rats (Bray, 1977). These studies support the finding that reduced feed intake in soy protein fed obese fa/fa Zucker rats did not affect their final body weight.

Urine protein to urine creatinine is expressed to overcome the possible misinterpretation of higher total urinary protein excretion because of higher total volume seen in fa/fa rats. The fa/fa rats had a $169 \%$ higher urinary protein/creatinine ratio compared to the lean rats. However, there were no significant effects of diet shown in this ratio. Twelve-hour total urinary creatinine excretion was lower in fa/fa rats compared to lean rats; CTL fed rats had significantly lower (12 hr) urine creatinine than soy fed rats (Appendix 7.5). The $f a / f a$ rats are known to have an altered renal structure and impaired renal function, as evidenced by larger glomerular area and proteinuria, respectively (Bray, 1977; Janssen et al., 1999). Since creatinine cannot be properly excreted in the urine due to impaired renal function in fa/fa rats compared to lean rats, one might expect it to build up in the serum. Interestingly, however, no significant effects were found in serum creatinine, creatinine clearance, or creatinine clearance relative to $100 \mathrm{~g}$ body weight (Appendix 7.5). 
Since a higher MGV is indicative of impaired renal function in the fa/fa rat model, attenuating this enlargement by soy protein would likely be beneficial. Glomerular hypertrophy, which has been proposed as an independent risk factor for the progression of renal disease and has been observed in the obese Zucker rat as evidenced by larger MGV in the fa/fa rats compared to lean rats, agrees with our previous studies and other studies (Herchak, 2005; Kasiske et al, 1985; Maddox et al., 202; Warford, 2003). In the present study, the soy protein diet provides protection against the progression of glomerular injury, as demonstrated by reduced MGV.

In this study, there were no significant diet or genotype effects for cytosolic and particulate $\mathrm{CPLA}_{2}$. Our previous study showed that dietary soy protein attenuated the higher protein levels of particulate $C P L A_{2}$ in the Han:SPRD-cy rat (Peng, 2005). Cytosolic cPLA 2 protein expression was higher in the obese fa/fa Zucker rat, the same rat model as in the current study (Herchak, 2005). The enzyme $\mathrm{CPLA}_{2}$ is known to responsible for the first step of prostanoid synthesis by releasing arachidonic acid (AA) from membrane phospholipids. Cytosolic $\mathrm{CPLA}_{2}$ is an inactive form and is stimulated by cytosolic-free calcium, then becomes activated by binding to cellular membranes (Evans et al., 2001; Hirabayashi \& Shimizu, 2001; Kramer \& Sharp, 1997).

No significant effects were observed for this protein level in this study with in the same rat model but particulate $\mathrm{CPLA}_{2}$ was higher in the fa/fa rats compared to lean rats (Warford, 2003). This might be because of the different diet effects or different progression of renal disease. Even though dietary soy protein 
attenuated the higher protein levels of particulate $\mathrm{CPLA}$ in rats with renal cyst disease, the animal model is different and with that model dietary soy protein did not alter $\mathrm{CPLA}_{2}$ in the cytosolic fraction or COX-1 and COX-2 enzyme levels.

In this current study, renal prostanoids were generally not altered by diet; there were few genotype effects on the endogenous or in vitro synthesized levels, and diet had no effect on these prostanoid levels, however, renal 6-keto PGF $1 a$ levels were lower in rats fed soy protein. One of our previous studies showed that dietary soy protein feeding lowered the in vitro steady-state levels of $\mathrm{TXB}_{2}$ and attenuated COX activity that produced $\mathrm{TXB}_{2}$ (Peng, 2005). Increased $\mathrm{PGE}_{2}$ levels in diseased kidneys by dietary soy protein was found in weanling Han:SPRD-cy rats at 1 and 3 wk compared to control diet (Fair et al., 2004).

Studies have revealed that soy protein intake ameliorates progression of renal disease. In $\mathrm{db} / \mathrm{db}$ mice, which are a model of type 2 diabetes and diabetic nephropathy, dietary soy protein slows development of diabetic nephropathy (Teixerira et al., 2003). It also reduces renal cysts and renal fibrosis in animal models of renal cyst disease (Ogborn et al., 1998; Ogborn et al., 2000; Tomobe et al., 1998). Even in aging Fischer 344 rats dietary soy protein feeding increases life span and decreases renal pathology (Iwasaki et al., 1988; Sisk et al., 2001). In the obese fa/fa Zucker rat model, which is the same rat model used in our study except that the rats were older (24 wk) and kidney disease was established, a soy protein diet $(23 \%)$ slows the development of proteinuria and glomerular injury in adult rats (Maddox et al., 2002). 
Even though the exact mechanism of the renal soy protective effect is not established, specific components in soy protein compared with egg white protein may be responsible for these dietary effects.

Isoflavones, a component in soy protein, have been shown to possess antiproliferative and anti-inflammatory properties. It has been reported that genistein can inhibit protein tyrosine kinase that is associated with cellular receptors for growth factors and transcription factors involved in cell inflammation and oxidative stress (Akiyama et al., 1987; Setchell, 1998). Renal protective effects of isoflavones also could result from anti-oxidant properties, which could not only interfere with formation of free radicals, but also result in enhancing nitric oxide availability, an important factor in defining the progression rate of renal disease.

Several studies have reported that nitric oxide synthesis is reduced in both humans and animals with renal disease suggesting that an impaired nitric oxide synthetic pathway may have an important role associated with the progression of renal disease (Schmidt and Baylis, 2000; Wagner et al., 2002). Recently Trugillo et al. demonstrated that dietary soy protein improved urinary nitrites and nitrates excretion compared to dietary casein in obese Zucker rats. This result is associated with improvement of renal function evidenced by less proteinuria, glomerulosclerosis, tubular dilation, and interstitial fibrosis (Trugillo et al., 2005).

In conclusion, our present study indicates that dietary soy protein attenuates early renal development showing smaller MGV and kidney weight relative to body weight in the fa/fa rat model of OAN. This protective effect of soy protein may be related to specific effects on renal 6-keto $\mathrm{PGF}_{1 \alpha}$ prostanoid production. It 
is reported that approximately 9 million American children over 6 years of age are considered obese (Lobstein et al., 2004). This leads to a concern regarding the potential impact of obesity in children on later health related to kidney disease. Therefore, an early intervention to prevent and/or delay OAN would have significant benefits.

\section{Strengths and Limitations}

A strong point of this study is the animal model used. The male obese fa/fa Zucker rat is a good model of obesity and metabolic syndrome. Therefore, investigations involving dietary intervention during this disease state may aid in early amelioration of renal disease progression and/or even the prevention of renal disease.

Another strength is that dietary intervention began at an early stage in disease progression. It is important to focus on prevention strategies of kidney disease before the disease has significantly progressed. Therefore, the beneficial effects observed in this study may provide a potential approach to have more impact on renal disease progression when dietary soy protein intervention is started earlier.

Another strength of this study is that, to the writer's knowledge, it is the first study investigating the effect of dietary soy protein intervention to determine prostanoid production and prostanoid enzyme activities in the obese fa/fa Zucker rat model. 
Several limitations exist in this present study. One limitation of this study is that this study was done using a rat model instead of humans. Even though the animal model used in this current study is a good model to study OAN since this rat model closely resembles human obesity, a human trial is necessary to compare what we have found with respect to beneficial effects of dietary soy protein. Another limitation of this study is that all parameters investigated were done only at the end of study. Therefore, conclusions regarding changes of the disease progression could not be stated.

Another limitation is that body composition was not analyzed in these rats, which made it difficult to interpretate the data with kidney weights expressed by body weights.

Another limitation of this study is that the soy protein we used is not a pure protein. Therefore, we are not able to determine if the beneficial effects of soy protein intervention observed in our study are caused by biologically active compounds within the soy protein isolate or by soy protein itself.

\section{Future Research}

For further investigations of dietary soy protein in OAN, there are several potential directions to follow:

- Measure individual renal prostanoid production and COX isoforms in different renal cell types. Renal prostanoids and COX isoforms are not present homogenously in kidneys; therefore, detecting their specific distribution and their 
changes by dietary soy protein intervention would help to establish the mechanisms of beneficial effects of soy protein on OAN.

- Try different amounts of soy protein. In the current study, only one level of soy protein $(20 \%)$ was used. Therefore, studies examining whether or not higher amounts of soy protein would result in greater reductions in the progression of OAN, as well as regarding the optimal amount of soy protein might be drawn in the future.

- Measuring prostanoid production from the series 1 and 3 during the progression of renal disease would give better understanding of the effects of prostanoids in OAN. 


\section{References}

Abrass CK, Spicer D, \& Raugi GJ. Induction of nodular sclerosis by insulin in rat mesangial cells in vitro studies of collagen. Kidney Int 56: 860-872, 1999.

Abrass CK. Overview: Obesity: What does it have to do with kidney disease? J Am Soc Nephrol 15: 2768-2772, 2004.

Akiyama T, Ishida J, Nakagawa S, Ogawara H, Watanabe SI, Itoh N, Shibuya M, \& Fukami Y. Genistein, a specific inhibitor of tyrosine-specific protein kinases. $J$ Biol Chem 262: 5592-5595, 1987.

Alyestrand A, Ahlberg M, \& Bergstrom J. Retardation of the progression of renal insufficiency in patients treated with low protein diets. Kidney Int 24 (Suppl 6): S268-S272, 1983.

Anderson JW, Blake JE, Turner J, \& Smith BM. Effecs of soy protein on renal function and proteinuria in patients with type 2 diabetes. Am J Clin Nutr 68 (Suppl): 1347S-1353S, 1998.

Aukema HM, Ogborn MR, Tomobe K, Takahashi H, Hibino T, \& Houlb B. Effects of dietary protein restriction and oil type on the early progression of murine polycystic kidney disease. Kidney Int 42: 837-842, 1992.

Aukema HM, Housini I, \& Rawling J. Dietary soy protein effects in inherited polycystic kidney disease are influenced by gender and protein level. J Am Soc Nephrol 10: 300-308, 1999.

Aukema HM, Adolphe J, Mishra S, Jiang J, Cuozzo FP, \& Ogborn MR. Alterations in renal cytosolic phospholipase $\mathrm{A}_{2}$ and cyclooxygenase in polycystic kidney disease. FASEB 17(2):298-300, 2002.

Bagby SP. Obesity-initiated metabolic syndrome and the Kidney: A recipe for chronic kidney disease? J Am Soc Nephrol 15: 2775-2791, 2004.

Baur LA. The international journal of pediatric obesity. Int J Pediatr Obesity 1: 5-6, 2006.

Bonnet F, Deprele C, Sassolas A, Moulin P, Alamartine E, Berthezene F, \& Berthoux $F$. Excessive body weight as a new independent risk factor for clinical and pathological progression in primary IgA nephritis. Am J Kidney Dis 37: 720727, 2001.

Bosma RJ, van der Heide JJ, Oosterop EJ, de Jong PE, \& Navis G. Body mass index is associated with altered renal hemodynamics in non-obese healthy subjects. Kidney Int 65: 259-265, 2004. 
Bradford MM. A rapid and sensitive method for the quantitation of microgram quantities of protein utilizing the principle of protein-dye binding. Anal Biochem 72: 248-254, 1976.

Brater DC, Harris C, Redfern JS, \& Gertz BJ. Renal effects of COX-2-selective inhibitors. Am J Nephrol 21: 1-15, 2001.

Bray GA. The Zucker-fatty rat: a review. Fed Proc 36: 148-153, 1977.

Brenner BM, Meyer TW, \& Hostetter TH. Dietary protein intake and the progressive nature of kidney disease: the role of hemodynamically mediated glomerular injury in the pathogenesis of progressive glomerular sclerosis in aging, renal ablation and intrinsic renal disease. N Engl J Med 307: 652-659, 1982.

Breyer M \& Badr K. Arachidonic acid metabolites and the kidney, in The Kidney, edited by Brenner B, 5 ed, W.B. Saunders Co, p.754-788, 1996.

Campean V, Theilig F, Paliege A, Breyer M, \& Bachmann S. Key enzymes for renal prostaglandin synthesis:site-specific expression in rodent kidney (rat, mouse). Am J Physiol Renal Physiol 285: F19-F32, 2003.

Castellani S, Paniccia R, Serio CD, Cava GL, Poggesi L, Fumagalli S, Gensini GF, \& Serneri GN. Thromboxane inhibition improves renal perfusion and excretory function in severe congestive heart failure. J Am Coll Cardiol 42 (1): 133-139, 2003.

Chagnac A, Weinstein T, Korzets A, Ramadan E, Hirsch J, \& Gafter U. Glomerular hemodynamics in severe obesity. Am J Physiol Renal Physiol, 278: F817-F822, 2000.

Chen J, Muntner P, Hamm LL, Jones DW, Batuman V, Fonseca V, Whelton PK, \& He J. The metabolic syndrome and chronic kidney disease in U.S. adults. Ann Intern Med 140: 167-174, 2004.

Chua Jr. SC, Chung WK, Wu-Peng XS, Zhang Y, Liu S-M, Tartaglia L, \& Leibel $\mathrm{RL}$. Phenotypes of mouse diabetes and rat fatty due to mutations in the OB (leptin) receptor. Science, 271(5251), 994-996, 1996.

Coimbra TM, Janssen U, Gröne, HJ, Ostendorf T, Kunter U, Schmidt H, Brabant $\mathrm{G}$, \& Floege J. Early events leading to renal injury in obese Zucker (fatty) rats with type II diabetes. Kidney Int, 57, 167-182, 2000.

Considine RV, Sinha MK, Heiman ML, Kriauciunas A, Stephens TW, Nyce MR, Ohannesian JP, \& Marco CC. Serum immunoreactive leptin concentrations in normal-weight and obese humans. N Engl J Med 334: 292-295, 1996. 
Csernus K, Lanyi E, Erhardt E, \& Molnar D. Effect of childhood obesity and obesity-related cardiovascular risk factors on glomerular and tubular protein excretion. Eur J Pediatrics 164: 44-49, 2005.

Dey A, Maric C, Kaesemeyer WH, Zaharis CZ, Stewart J, Pollock JS, \& Imig JD. Rofecoxib decreases renal injury in obese Zucker rats. Clin Sci 107: 561-570, 2004.

Dhaene M, Sabot JP, Philippart Y, Doutrelepont JM, \& Vanherweghem JL. Effects of acute protein loads of different sources on glomerular filtration rate. Kidney Int 32 (Suppl 22): S25-S28, 1987.

Don BR, Blake S, Hutchison FN, Kaysen GA, \& Schambelan M. Dietary protein intake modulates glomerular eicosanoid production in the rat. Am J Physiol 256: F711-F718, 1989.

Dupont J. Lipids. In Present Knowledge in Nutrition, $6^{\text {th }}$ edition (Brown ML, editor), p. 56-66. Washington DC:ILSI Press, 1990.

Ejerblad E, Fored CM, Lindblad P, Fryzek J, McLaughlin JK, \& Nyren O. Obesity and risk for chronic renal failure. J Am Soc Nephrol 17(6): 1695-1702, 2006.

Evans JH, Spencer DM, Zweifach A, \& Leslie CC. Intracellular calcium signals regulating cytosolic phospholipase $A_{2}$ translocation in internal membranes. J Biol Chem 276: 30150-30160, 2001.

Fair DE, Ogborn MR, Weiler HA, Bankovic-Calic N, Nitschmann EP, FitzpatrickWong SC, \& Aukema HM. Dietary soy protein attenuates renal disease progresson after 1 and 3 weeks in Han:SPRD-cy weanling rats. $J$ Nutr 134: 1504-1507, 2004.

Fan Y-Y \& Chapkin RS. Importance of dietary $Y$-linolenic acid in human health and nutrition. $J$ Nutr 128, 1411-1414, 1998.

Fitzferald GA, Healy C, \& Daugherty J. Thromboxane $A_{2}$ biosynthesis in human disease. Fed Proc 46: 154-158, 1987.

Goldstein BJ. Insulin resistance: From benign to type 2 diabetes mellitus. Reviews in Cardiovascular Medicine Abbre, 4(Suppl 6), S3-S10, 2003.

Hall JE, Crook ED, Jones DW, Wofford MR, \& Dubbert PM. Mechanisms of obesity-associated cardiovascular and renal disease. Am J Med Sci 324: 127137, 2002. 
Harris RC. Cyclooxygenase-2 in the kidney. J Am Soc Nephrol 11: 2387-2394, 2000.

Herchak DJ. Trans 10, cis 12 conjugated linoleic acid (T10, C12 CLA) is the isomer responsible for the benefical effect of dietary CLA in the kidneys of obese, insulin-resistant rats. Masters Thesis. University of Manitoba, 2005.

Hillege HL, Janssen WM, Bak AA, Diercks GF, Grobbee DE, Crijns HJ, Van Gilst WH, De Zeeuw D, \& De Jong PE for the PREVEND study group.

Microalbuminuria is common, also in nondiabetic, nonhypertensive population, and an independent indicator of cardiovascular risk factors and cardiovascular morbidity. J Inter Med 249: 519-526, 2001.

Hirabayashi T \& Shimizu T. Localization and regulation of cytosolic phospholipase A2. Biochim Biophys Acta 1488: 124-138, 2000.

Hirose K, Østerby R, Nozawa M, \& Gundersen HJ. Development of glomerular lesions in experimental long-term diabetes in the rat. Kidney Int 21(5): 689-695, 1982.

Hoffmans MD, Kromhout D, \& de Lezenne Coulander C. The impact of body mass index of 18-year old Dutch men on 32-year mortality from all causes. $J$ Clin Epidemiol 41: 749-756, 1988.

Hostetter TH. Prevention of the development and progression of renal disease. $J$ Am Soc Nephrol 14: S144-S147, 2003.

Imig JD. Eicosanoid regulation of the renal vasculature. Am J Physiol Renal Physiol 279: F965-F981, 2000.

Iseki K, Ikemiya Y, Kinjo K, Inoue T, Iseki C, \& Takishita S. Body mass index and the risk of development of end-stage renal disease in a screened cohort. Kidney Int 65: 1870-1876, 2004.

Iwasaki K, Gleiser CA, Masoro EJ, McMahan CA, Seo EJ, \& Yu BP. The influence of dietary protein source on longevity and age-related disease processes of Fischer rats. J Gerontol 43: B5-B12, 1988.

Janssen U, Phillips AO, \& Floege J. Rodent models of nephropathy associated with type II diabetes. J Nephrology 12: 159-172, 1999.

Jayapalan S, Saboorian MH, Edmunds JW, \& Aukema HM. High dietary fat intake increases renal cyst disease progression in Han:SPRD-cy rats. J Nutr 130: 2356-2360, 2000. 
Jiang X, Srinivasan SR, Urbina E, \& Berenson GS. Hyperdynamic circulation and cardiovascular risk in children and adolescents (The Bogalusa Heart Study).

Circulation 91: 1101-1106, 1995.

Jong PE, Verhave JC, Pinto-Sietsma SJ, \& Hillege HL. Obesity and target organ damage: the kidney. Int J Obesity 26 (Suppl 4): S21-S24, 2002.

Kasiske BL, Cleary MP, O'Donnell MP, \& Keane WF. Effects of genetic obesity on renal structure and function in the Zucker rat. J Lab Clin Med 106: 598-604, 1985.

Kasiske BL \& Crosson JT. Renal disease in patients with massive obesity. Arch Intern Med 146: 1105-1109, 1986.

Kasiske BL, O'Donnell MP, Lee H, Kim Y, \& Keane WF. Impact of dietary fatty acid supplementation on renal injury in obese Zucker rats. Kidney Int 39: 11251134, 1991.

Kasiske BL, Lakatua JDA, Ma JZ, \& Louis TA. A meta-analysis of the effects of dietary protein restriction on the rate of decline in renal function. Am J Kidney Dis 31(6): 954-961, 1998.

Klahr S, Levey AS, Beck GJ, Caggiula AW, Hunsicker L, Kusek JW, \& Striker G. Modification of Diet in Renal Disease Study Group. The effects of dietary protein restriction and blood-pressure control on the progression of chronic renal disease. N Engl J Med 31: 877-884, 1994.

Klahr S \& Purkerson ML. Effects of dietary protein on renal function and on the progression of renal disease. Am J Clin Nutr 47: 146-152, 1998.

Komers R, Zdychova J, Cahova M, Kazdova L, Lindsley JN, \& Anderson S. Renal cyclooxygenase-2 in obese Zucker (fatty) rats. Kidney Int 67: 2151-2158, 2005.

Komhoff M, Grone H-J, Klein T, Seyberth HW, \& Nusing RM. Localization of cyclooxygenase-1 and 2 in adult and fetal human kidney: implication for renal function. Am J Physiol 272: F460-F468, 1997.

Komhoff M, Seyberth HW, Nusing RM, \& Breyer MD. Cyclooxygenase-2 expression is associated with the macula densa in kidneys from patients with Bartter-like syndrome. J Am Soc Nephrol 10: 437A, 1999.

Kontessis P, Jones S, Dodds R, Trevisan R, Nosadini R, Fioretto P, Borsato M, Sacerdoti $D, \&$ Viberti $G$. Renal, metabolic and hormonal responses to ingestion of animal and vegetable proteins. Kidney Int 38: 136-144, 1990. 
Kramer RM \& Sharp JD. Structure, function and regulation of $\mathrm{Ca}^{2+}$ sensitive cytosolic phospholipase A2. Fed Eur Biochem Soc Lett 410: 49-53, 1997.

Kuczmarski RJ \& Fleqal KM. Criteria for definition of overweight in transition: background and recommendations for the United States. Am J Clin Nutr 72 (5): 1067-1068, 2000.

Lambert M, Paradis G, O'Loughlin J, Delvin EE, Hanley JA, \& Levy E. Insulin resistance syndrome in a representative sample of children and adolescents from Quebec, Canada. Int Obesity, 28, 833-841, 2004.

Lobstein T, Baur L, \& Uauy R. Obesity in children and young people: A crisis in public health. Report of the International Obesity Task Force Childhood Obesity Working Group. Obesity Reviews 5: 4-104, 2004.

Lorenzo C, Okoloise M, Williams K, Stern MP, \& Haffner SM. The metabolic syndrome as predictor of type 2 diabetes. Diabetes Care, 26, 3153-3159, 2003.

Lu J, Darnley MG, \& Aukema HM. Dietary fat effects on kidey disease are greater in males compared to females in CD1-pcy/pcy mice. FASEB 13: A935, 1999.

Lu J, Bankovic-Calic N, Ogborn M, Saboorian H, \& Aukema HM. Detrimental effects of a high fat diet in early renal injury are ameliorated by fish oil in Han:SPRD-cy rats. J Nutr 133: 180-186, 2003.

Maddox DA, Alavi FK, Silbernick EM, \& Zawada ET. Protective effects of a soy diet in preventing obesity-linked renal disease. Kidney Int 61: 96-104, 2002.

Maschio G, Oldrizzi L, Tessitore N, D'Angelo A, Valvo E, Lupo A, Loschiavo C, Fabris A, Gammaro L, Rugiu C, \& Panzetta G. Early dietary protein and phosphorus restriction is effective in delaying progression of chronic renal disease. Kidney Int 24 (Suppl 16): S273-277, 1983.

Messina M. Modern application for an ancient bean: Soybeans and the prevention and treatment of chronic disease. J Nutr 125: 567S-569S, 1995.

Mogensen CE. Prediction of clinical diabetic nephropathy in IDDM patients. Alternatives to microalbuminuria. Diabetes 39: 761-767, 1990.

Mossberg HO. 40-year follow-up of overweight children. Lancet 2: 491-493, 1989.

Must A, Jacques PF, Dallal GE, Bajema CJ, \& Dietz WH. Long-term morbidity and mortality of overweight adolescents. A follow-up of the Harvard Growth Study of 1922 to 1935. N Engl J Med 327: 1350-1355, 1992. 
Nasrallah R \& Hebert RL. Prostacyclin signaling in the kidney: implications for health and disease. Am J Physiol Renal Physiol 289: F235-F246, 2005.

National Cholesterol Education Program. Third report of the national cholesterol education program (NCEP) expert panel on detection, evaluation, and treatment of high blood cholesterol in adults (adult treatment panel III) final report. Circulation, 106 (25), 3143-3421, 2002.

Nantel F, Meahows E, Denis D, Connolly B, Meters KM, \& Giaid A. Immunolocalization of cyclooxygenase-2 in the macula densa of human elderly. FEBS Lett 457: 475-477, 1999.

National Kidney Foundation. K/DOQI clinical practice guidelines for chronic kidney disease: evaluation, classification, and stratification. Am J Kidney Dis, 39 (Suppl 1), S1-S256, 2002.

Needleman P, Turk J, Jakschik BA, Morrison AR, \& Lefkowith JB. Arachidonic acid metabolism. Annu Rev Biochem 55: 69-102, 1986.

Nitschmann E, Bankovic-Calic N, Aukema HM, \& Ogborn MR. Dietary supplementation with conjugated linoleic acid (CLA) attenuates fibrous and inflammation in the Han:SPRD-cy rat. J Am Soc Nephrol 12: 541A, 2001.

O'Donnell MP, Kasiske BL, Cleary MP, \& Keane WF. Effects of genetic obesity on renal structure and function in the Zucker rat. Micropuncture studies. $J$ Lab Clin Med 106: 605-610, 1985.

Ogborn MR \& Sareen S. Amelioration of polycystic kidney disease by modification of dietary intake in the rat. J Am Soc Nephrol 6: 1649-1654, 1995.

Ogborn MR, Bankovic-Calic N, Shoesmith C, Buist R, \& Peeling J. Soy protein modification of rat polycystic kidney disease. Am J Physiol 274: F541-F549, 1998.

Ogborn MR, Hope EN, Weiler H, Leswick D, \& Bankovic-Calic N. Flaxseed ameliorates interstitial nephritis in rat polycystic kidney disease. Kidney Int 53: 417-423, 1999.

Ogborn MR, Nitschmann E, Weiler HA, \& Bankovic-Calic N. Modification of polycystic kidney disease and fatty acid status by soy protein diet. Kidney Int 57 : 159-166, 2000.

Ogborn MR, Nitschmann E, Bankovic-Calic N, Weiler HA, Fitzpatrick-Wong S, \& Aukema HM. Dietary conjugated linoleic acid reduces $\mathrm{PGE}_{2}$ release and interstitial injury in rat polycystic kidney disease. Kidney Int, 64, 1214-1221, 2003. 
Peng C. Dietary soy protein and renal disease selectively alter cyclooxygenase isoforms and prostanoid production in Han:SPRD-cy rats. Masters Thesis. University of Manitoba, 2005.

Perazella MA. COX-2 selective inhibitors: analysis of the renal effects. Expert Opin Drug Saf 1(1): 53-64, 2002.

Pedraza-Chaverri J, Barrera D, Hernandez-Pando R, Medina-Campos ON, Cruz C, Murguia F, Juarez-Nicolas C, Correa-Rotter R, Torres N, \& Tovar AR. Soy protein diet ameliorates renal nitrotyrosine formation and chronic nephropathy induced by puromycin aminonucleoside. Life Sci 74: 987-999, 2004.

Pedrini MT, Levey AS, Lau J, Chalmers TC, \& Wang PH. The effect of dietary protein restriction on the progression of diabetic and nondiabetic renal diseases: A meta-analysis. Ann Intern Med 124: 627-632, 1996.

Phillips AO, Janssen U, \& Floege J. Progression of diabetic nephropathy. Kidney Blood Press Res 22: 81-97, 1999.

Pinto-Sietsma SJ, Janssen WMT, Hillege HL, Navis GJ, de Zeeuw D, \& de Jong $P E$ for the PREVEND study group. Urinary albumin excretion is associated with renal functional abnormalities in a nondiabetic population. J Am Soc Nephrol 11: 1882-1888, 2000.

Praga M, Hernandez E, Herrero JC, Morales E, Revilla Y, Diaz-Gonzalez R, \& Rodicio JL. Influence of obesity on the appearance of proteinuria, and renal insufficiency after unilaternal nephrectomy. Kidney Int 58: 2111-2118, 2000.

Rahman MA, Stork JE, \& Dunn MJ. The role of eicocanoids in experimental glomerulonephritis. Kidney Int 32, S40-S48, 1987.

Reilly JJ, Methven E, McDowell ZC, Hacking B, Alexander D, Stewart L, \& Kelnar CJ. Health consequences of obesity. Arch Dis Child 88: 748-752, 2003.

Ribstein J, du Cailar G, \& Mimran A. Combined renal effects of overweight and hypertension. Hypertension 26: 610-615, 1995.

Rozen S \& Skaletsky H. Primer3 on the WWW for general users and for biologist programmers. In: Bioinformatics Methods and Protocols: Methods in Molecular Biology, edited by Krawetz S and Misener S. Totowa, NJ:Humana p. 365-386, 2000.

Schmidt RJ \& Baylis C. Total nitric oxide production is low in patients with chronic renal disease. Kidney Int 58: 1261-1266, 2000. 
Setchell K. Phytoestrogens: The biochemistry, physiology, and implications for human health of soy isoflavones. Am J Clin Nutr 68: S1333-S1348, 1998.

Shimokawa I, Higami Y, Hubbard GB, McMahan CA, Masoro EJ, \& Yu BP. Diet and the suitability of the male fischer 344 rat as a model for aging research. $J$ Gerontol 48(1): B27-B32, 1993.

Sisk MB, Hausman DB, Martin RJ, \& Azain MJ. Dietary conjugated linoleic acid reduces adiposity in lean but not obese Zucker rats. J Nutr 131: 1668-1674, 2001.

Smith PK, Krohn RI, Hermanson GT, Maillia AK, Gartner FH, Provenzano MD, Fujimoto EK, Goeke NM, Olson BJ, \& Klenk DC. Measurement of protein using bicinchoninic acid. Analy Biochem 150 (1): 76-85, 1985.

Smith WL and Murphy RC. Chapter 13: The Eicosanoids: Cyclooxygenase, Lipoxygenase, and Epoxygenase Pathways. Biochemistry of Lipids, Lipoproteins and Membranses, $4^{\text {th }}$ ed. Vance DE, Vance JE. Elsevier Science Publishers B.V., Amsterdam, The Netherlands, 2002.

Speiser PW, Rudolf MC, Anhalt H, Camacho-Hubner C, Chiarelli F, Eliakim A, Freemark M, Gruters A, Hershkovitz E, lughetti L, Krude H, Latzer Y, Lusing RH, Pescovitz OH, Pinhas-Hamiel O, Rogol AD, Shalitin S, Sultan C, Stein D, Vardi P, Wagner L, Riggleman A, Erdely A, Couser W, \& Baylis C. Reduced nitric oxide synthase activity in rats with chronic renal disease due to glomerulonephritis. Kidney Int 62: 532-536, 2002.

Werther GA, Zadik Z, Zuckerman-Levin N, \& Hochberg Z: Obesity Consensus Working Group. Childhood obesity. J Clin Endocrinol Metab 90: 1871-1887, 2005.

Srinivasan SR, Bao W, Wattigney WA, \& Berenson GS. Adolescent overweight is associated with adult overweight and related multiple cardiovascular risk factors: the Bogalusa Heart Study. Metabolism 45: 235-240, 1996.

Srivastava T. Nondiabetic consequences of obesity on kidney. Pediatr Nephrol 21: 463-470, 2006.

Stahl RAK, Kudelka S, \& Helmchen U. High protein intake stimulates glomerular prostaglandin formation in remnant kidneys. Am J Physiol 252: F1088-F1094, 1987.

Statistic Canada. The prevalence of obesity in Canada. www.statcan.ca

Teixeira SR, Tappenden KA, \& Erdman, JW, Jr. Altering dietary protein type and quantity reduces urinary albumin excretion without affecting plasma glucose concentrations in BKS.cg-m + Lepr db+Lepr $d b(d b / d b)$ mice. J Nutr 133: 673678, 2003. 
Tomobe K, Philbrick DJ, Aukema HM, Clark WF, Ogborn MR, Parbtani A, Takahashi H, \& Holub BJ. Early dietary protein restriction slows disease progression and lengthens survival in mice with polycystic kidney disease. J Am Soc Nephrol 5: 1355-1360, 1994.

Tomobe K, Philbrick DJ, Ogborn MR, Takahashi H, \& Holub BJ. Effect of dietary soy protein and genistein on disease progression in mice with polycystic kidney disease. Am J Kidney Dis 31(1): 55-61, 1998.

Tovar AR, Murguia F, Cruz C, Hernandez-Pando R, Aguilar-Salinas CA, Pedraza-Chaverri J, Correa-Rotter R, \& Torres N. A soy protein diet alters hepatic lipid metabolism gene expression and reduces serum lipids and renal fibrogenic cytokines in rats with chronic nephritic syndrome. J Nutr 132: 25622569, 2002.

Troiano RP, Flegal KM, Kuczmarski RJ, Campbell SM, \& Johnson CL. Overweight prevalence and trends for children and adolescents. The National Health and Nutriton Examination Surveys, 1963 to 1991. Arch Pediatr Adolesc Med 149: 1085-1091, 1995.

Trugillo J, Ramirez V, Perez J, Torre-Villalvazo I, Torres N, Tovar AR, Munoz RM, Uribe N, Gamba G, \& Bobadilla NA. Renal protection by a soy diet in obese Zucker rats is associated with restoration of nitric oxide generation. Am J Physio/Renal 288: 108-116, 2005.

Tucker BJ, Anderson CM, Scott Thies R, Collins RC, \& Blantz RC. Glomerular hemodynamic alterations during acute hyperinsulinemia in normal and diabetic rats. Kidney Int 42: 1160-1168, 1992.

Tuttle KR. Renal manifestations of the metabolic syndrome. Nephrol Dial Transplant 20: 861-864, 2005.

United States Renal Data System (USRDS). Annual data report: Atlas of endstage renal disease in the United States, National Institutes of Health, National Institute of Diabetes and Digestive and Kidney Diseases. Retrieved June 2005. Bethesda, MD, 2004. Website:http://www.usrds.org.

Vane JR, Bakhle YS, \& Botting RM. Cyclooxygenases 1 and 2. Annu Rev Pharmacol Toxicol 38:97-120, 1998.

Verhave JC, Hillege HL, Burgerhof JGM, Navis GJ, de Zeeuw D, \& de Jong PE for the PREVEND study group. Impact of sodium intake on urinary albumin excretion is enhanced by obesity. J Am Soc Nephrol 13: 661-662A, 2002. 
Viberti G, Bognetti E, Wiseman M, Dodds R, Gross J, \& Keen H. Effect of protein-restriction diet on renal response to a meat meal in humans. $A m \mathrm{~J}$ Physiol 253: F388-393, 1987.

Visser M, Bouter LM, McQuillan GM, Wener MH, \& Harris TB. Elevated C-reative protein levels in overweight and obese adults. JAMA 282: 2131-2135, 1999.

Warford L. Dietary conjugated linoleic acid (CLA) reduces protein level of cytosolic phospholipase $A_{2}$ and peroxisome proliferators-activated receptor alpha and ameliorates early renal progression in obese fa/fa Zucker rats. Masters Thesis. University of Manitoba, 2003.

Warford-Woolgar L, Peng C, Shuhyta J, Wakefield A, Sankaran D, Ogborn M, \& Aukema HM. Selectivity of cyclooxygenase isoforrm activity and prostanoid production in normal and diseased Han:SPRD-cy rat kidneys. Am J PhysiolRenal 290: 897-904, 2006.

Weibel ER \& Gomez DM. A principle for counting tissue structures on random sections. J Appl Physiol 17 (2): 343-348, 1962.

Williams AJ, Baker F, \& Walls J. Effect of varying quantity and quality of dietary protein intake in experimental renal disease in rats. Nephron 46: 83-90, 1987.

Williams AJ \& Walls J. Metabolic consequences of differing protein diets in experimental renal disease. Eur J Clin Invest 17: 117-122, 1987.

Wilton DC \& Waite M. Chapter 11: Phospholipases. Biochemistry of Lipids, Lipoproteins and Membranes, $4^{\text {th }}$ ed. Vance DE, Vance JE (Eds). Elsevier Science Publishers B.V., Amsterdam, The Netherlands, 2002.

Wheeler DC, Nair DR, Persaud JW, Jermey JY, Chappell ME, Varghese Z, \& Moorhead JF. Effects of dietary fatty acids in an animal model of focal glomerulosclerosis. Kidney Int 39: 930-937, 1991.

Wolf G, Hamann A, Han DC, Helmchen U, Thaiss F, Ziyadeh FN, \& Stahl RAK. Leptin stimulates proliferation and TGF- $\beta$ expression in renal glomerular endothelial cells: potential role in glomerulosclerosis. Kidney Int 56: 860-872, 1999.

Wolf G, Chen S, Han DC, \& Ziyadeh FN. Leptin and renal disease. Am J Kidney Dis 39: 1-11, 2002.

Xu ZG, Lanting L, Vaziri ND, Li Z, Sepassi L, Rodriguez-Iturbe B, \& Natarajan R. Upregulation of angiotensin II type 1 receptor, inflammatory mediators, and enzymes of arachidonate metabolism in obese Zucker rat kidney. Reversal by angiotensin II type 1 receptor blockade. Circulation 111: 1962-1969, 2005. 
Yamaguchi T, Valli VE, Philbrick D, Holub B, Yoshida K, \& Takahashi H. Effects of dietary supplementation with fatty acids on kidney morphology and the fatty acid composition of phospholipids and triglycerides from mice with polycystic kidney disease. Res Commun Chem Pathol Pharmacol 69: 335-351, 1990.

Yamagisawa H, Morrissey J, Kurihara N, Wada O, \& Klahr S. Effects of dietary protein on glomerular eicosanoid production in rats with bilateral ureteral obstruction. Proc Soc Exp Biol Med 207: 234-241, 1994.

Yamagisawa $\mathrm{H} \&$ Wada $\mathrm{O}$. Effects of dietary protein on eicosanoid production in rat renal tubules. Nephron 78: 176-186, 1998.

Yamagisawa H, Morrissey J, Morrison AR, Purkerson ML, \& Klahr S. Role of ANG II in eicosanoid productin by isolated glomeruli from rats with bilateral ureteral obstruction. Am J Physiol 258: F85-F93, 1990.

Yudkin JS, Stehouwer CDA, Emeis JJ, \& Coppack SW. C-reactive protein in healthy subjects: association with obesity, insulin resistance and endothelial dysfunction. A potential role for cytokines originating from adipose tissue. Arteroscler Thromb Vasc Biol 19: 972-978, 1999.

Zeller K, Whittaker E, Sullivan L, Raskin P, \& Jacobson HR. Effect of restricting dietary protein on the progression of renal failure in patients with insulindependent diabetes mellitus. N Engl J Med 324: 78-84, 1991

Zeller KR. Low-protein diets in renal disease. Diabetes Care 14(9): 856-866, 1991. 


\section{APPENDIX (Details of Methods)}

\subsection{Mean Glomerular Volume (MGV)}

Kidneys removed from phosphate-buffered formalin (PBF) were placed in phosphate-buffered saline (PBS), were embedded in paraffin wax, and were sectioned at 5 microns using a Microtome (American Optical 820, Southbridge, Massachusetts). Kidney sections were then placed in xylene to remove the paraffin and stained with hematoxylin and eosin. The kidney sections were stained in Harris's hematoxylin for 5 minutes, washed with deionized water, placed in $1 \% \mathrm{HCL}$ in deionized water and then placed in $2 \%$ ammonia water. Hematoxylin stains nuclei and ribosomes blue. The kidney sections were then washed with deionized water and stained with eosin for 3 minutes, and dehydrated with alcohol. Eosin stains the kidney proteins pink. Cover slips were mounted with cytoseal.

Identification of stained slides of kidney-cross sections was blinded to remove potential bias during analysis by microscopy. Thirty randomly chosen glomeruli per kidney were captured using a camera (Spot Diagnostic Instruments, Inc., Sterling Heights, Michigan) attached to an Olympus BX60 microscope (Olympus Optical Company, Hamburg, Germany). Slides were analyzed using a 20X objective starting from the left edge of the kidney sections and moving to the right. The pictures were sequentially taken using a Spot Advanced software program version 3.0.1 (Diagnostic Instruments Inc, Sterling Heights, Michigan). Captured images of glomeruli were measured using the Image Pro Plus software program (Media Cybernetics, Del Mar, California). A 20X calibration grid was first 
opened, and then the file to be analyzed was opened. The largest diameter across each whole glomerulus in the picture was measured. The values for glomerular were exported into a Microsoft Excel file. Each diameter was measued in $\mu \mathrm{m}$.

MGV was calculated using the method first described by Weibel \& Gomez (1962). In order to calculate MGV, an average glomerular diameter was first calculated for each rat and then this number was divided by 2 to give an average radius for each kidney. A mean glomeurlar area (MGA) was calculated for each rat using the formular as MGA $=\pi r^{2}$ (the area of a circle). MGV was calculated using the formula as MGV $=1.25 \times(M G A)^{3 / 2}$ where the value 1.25 is derived from $\beta / K$, where $\beta$ depends on the shape of the object and is equal to 1.38 for a sphere and $\mathrm{K}$ is a distribution coefficient and is equal to 1.10 .

\subsection{Measurement of Steady-State Protein Levels of Enzymes Involved in Prostanoid Production}

\subsubsection{Lyophilization of Kidneys}

The left kidney from each rat was lyophilized in preparation for western immunoblotting of steady-state protein levels of $\mathrm{CPLA}_{2}, \mathrm{COX}-1$, and COX-2. The left kidney was removed from the $-80^{\circ} \mathrm{C}$ freezer. The frozen kidney was cut up into small pieces and placed into a pre-weighed $15 \mathrm{~mL}$ disposable sterile centrifuge tube (Fisher Scientific, cat no 05-539-5, Nepean, Ontario) topped with a lid that had ventilation holes. The tube containing the cut up kidney was weighed again and the initial weight of the frozen kidney was recorded. Tubes 
were immersed in liquid nitrogen and then placed in a pre-cooled $\left(-40^{\circ} \mathrm{C}\right)$ lyophilizer (Labconco, Model No $4451 \mathrm{~F}$, Kansas City, Missour) so that samples could begin drying. The freeze dryer was checked periodically and the tubes were removed from the freeze dryer and weighed every few hours or after an overnight drying period until two consecutive equal weights were obtained. The freeze drying process was complete when two consecutive equal tube weights were obtained. If the weight was not equal, the tube was placed back into liquid nitrogen and was returned to the freezer dryer to dry again. Dry kidneys were pulverized using a spatula. The lid without holes was used to replace the lid with holes. Samples were stored at $-80^{\circ} \mathrm{C}$.

\subsubsection{Homogenization of Kidneys}

Twenty mg of pulverized kidney was weighed into labeled glass, roundbottomed tubes submerged on ice. This was homogenized in 100 volumes of icecold cytosolic homogenization buffer twice for 30 seconds each time using a Polytron homogenizer (Brinkmann Instruments, Type PT 1020 350D, Rexdale, Ontario) on a speed control setting of 5. Cytosolic homogenization buffer contained $500 \mathrm{mM}$ Tris (Fisher Scientific, Mississauga, Ontario), $0.5 \mathrm{M}$ sucrose, $200 \mathrm{mM}$ ethylene-diamine-tetraacetic aicd (EDTA) pH 7.6, $100 \mathrm{mM}$ ethylene glycol-bis ( $\beta$-aminoehtyle ether) N, N, N', N'-tetraacetic aicd (EGTA) pH 7.6, 0.4 $\mathrm{M} \mathrm{NaF}, 10 \mathrm{mM}$ sodium orthovanadate, $2.5 \mathrm{mg} / \mathrm{mL}$ aprotinin, $1 \mathrm{mg} / \mathrm{mL}$ leupeptin, $2.5 \mathrm{mg} / \mathrm{mL}$ pepstatin, $1 \mathrm{mg} / \mathrm{mL}$ soybean trypsin inhibitor (STI), $24 \mathrm{mg} / \mathrm{mL} 4-(2-$ aminoethyl) benzene-sulfonyl fluoride (ABSF), $\beta$-mercaptoethanol (Fisher 
Scientific, Mississauga, Ontario). The cytosolic homogenization buffer was prepared by first mixing all ingredients and then adding $5 \mathrm{M}$ sodium hydroxide ( $\mathrm{NaOH}$ salt, Fisher Scientific, s318-500, Napean, Ontario) to obtain a final pH of 7.2-7.4 of the solution. Homogenates were transferred into $5 \mathrm{~mL}$ ultracentrifuge tubes and balanced before a cold rotor was (Beckman Coulter, Inc., model no 50.3TI, Fullerton, California) placed in the pre-cooled $\left(4^{\circ} \mathrm{C}\right)$ ultracentrifuge (Beckman, model no L8-80). Samples were spun at 100,000 $\mathrm{xg}$ for 35 minutes. The cytosolic fraction remained in the supernatant. A transfer pipette was used to draw off the supernatant and the cytosolic fraction was placed into pre-labeled 2 $\mathrm{mL}$ microcentrifuge tubes (Fisher Scientific, cat no 05-408-141, Napean, Ontario) and immediately stored at $-80^{\circ} \mathrm{C}$.

The pellet was re-suspended in $0.4 \mathrm{~mL}$ (20 volumes) of particulate homogenization buffer and the tube was vortexed with a glass rod placed in it to disperse the remaining pellet in the particulate homogenization buffer which consisted of the cytosolic buffer plus $1 \%$ Triton X-100. After sitting on ice for 10 minutes, it was vortexed a second time. Tubes were balanced and spun at $100,000 \times \mathrm{g}$ for 35 minutes again. The particulate fraction was now suspended in the supernatant and was drawn off and placed into a pre-labeled $2 \mathrm{~mL}$ microcentrifuge tube (Fisher Scientific). The samples were immediately stored at $-80^{\circ} \mathrm{C}$. 


\subsubsection{Total Protein Determination}

Total protein was determined using the Bradford Method (Bradford, 1976) in cytosolic and particulate fractions. Wells in 96-well microplates were labeled as blank, standard or sample. Concentrations of standards were made ranging from $0.0625 \mathrm{mg} / \mathrm{mL}$ to $1 \mathrm{mg} / \mathrm{mL}$ using a $2 \mathrm{mg} / \mathrm{mL}$ bovine serum albumin (BSA) stock solution (Sigma, P0834, Oakville, Ontario). Kidney homogenates were diluted $20 X$ with deionized water. Ten $\mu \mathrm{L}$ of blank, standard or $20 \mathrm{X}$ diluted samples were added to wells in triplicate. Two hundred $\mu \mathrm{L}$ Bradford Reagent (Sigma, B6916, St. Louis, Missouri) was added to each well using a multi-channel pipette. Then the plate was covered with plastic film and mixed on an orbital shaker (Fisher Scientific, model no 361 Nepean, Ontario) for 15 minutes at room temperature. The plate was read at $595 \mathrm{~nm}$ using a microplate reader (Molecular Devices Corporation, SpectraMax 340, Sunnyville, California).

SOFTmax Pro software was used to calculate total protein concentration in the samples based on the equation devised from the standard curve. Final protein concentrations were determined by multiplying by the dilution factor (20fold diluted samples).

\subsubsection{Western Immunoblotting}

To separate steady-state protein levels of $\mathrm{CPLA}_{2}, \mathrm{COX}-1$, and COX-2 onedimensional sodium dodecyl sulfate polyacrylamide gel electrophoresis (SDSPAGE) was used as has been described (Aukema et al., 2002). This allows for 
protein separation as proteins migrate in an electrical field through pores in a gel. The combination of gel pore size, shape, and protein size determines the migration rate of each protein.

Two cleaned glass plates were placed with their sides together and spacers to separate the two plates. The plates were lined up and screwed into place on a gel module (Amersham Biosciences, part of Hoefer miniVE vertical electrophoresis system, 80-6418-77, Buckinghamshire, England) and then deionized water was poured out. A $7.5 \%$ separating gel solution consisted of $2670 \mu \mathrm{L}$ of deionized water, $1250 \mu \mathrm{L}$ of $1.5 \mathrm{M}$ tris aminomethane-hydrochloric acid (tris-HCL), $50 \mu \mathrm{L}$ of $10 \%$ (w/v) SDS (Fisher Scientific, BP166-100), $1000 \mu \mathrm{L}$ of $40 \%$ bis-acrylamide (Fisher Scientific, BP1408-1), $25 \mu \mathrm{L}$ of $10 \%(\mathrm{w} / \mathrm{v})$ ammonium persulfate (APS, Fisher Scientific, BP179-25), and $5 \mu \mathrm{L}$ of $N, N, N^{\prime}$, N',-tetramethylethylenediamine (TEMED, Fisher Scientific, BP150-20). The latter two ingredients were added just before the solution was added the space in between the plates using a Pasteur pipette until it reached about $3 / 4$ of the way up the plates. Then the gel was overlaid carefully with deionized water and it was left for 30 minutes to polymerize.

Once the gel was solidified, the water was poured off and a $4 \%$ stacking gel that contained $1625 \mu \mathrm{L}$ of deionized water, $625 \mu \mathrm{L}$ of $0.5 \mathrm{M}$ tris tris-HCL pH 6.8, $25 \mu \mathrm{L}$ of $10 \%$ (w/v) SDS (Fisher Scientific, BP166-100), $250 \mu \mathrm{L}$ of $40 \%$ bisacrylamide (Fisher Scientific, BP1408-1), $12.5 \mu \mathrm{L}$ of 10\% (w/v) APS (Fisher Scientific, BP179-25), and $2.5 \mu \mathrm{L}$ of TEMED (Fisher Scientific, BP150-20) was then added on top of the separating gel. Again, the TEMED and APS were added 
just before pouring the gel. In order to form lanes to load the protein samples a comb was inserted into the stacking gel and the stacking gel was allowed to polymerize for 45 minutes. The module of the gel was unclipped at the bottom and placed in the electrophoretic chamber filled with running buffer (this running buffer could be re-used up for 10 times) that was made as $10 \mathrm{X}$ running buffer and contained $29.0 \mathrm{~g}$ of tris base, $144.0 \mathrm{~g}$ glycine (Fisher Scientific BP381-1), $10.0 \mathrm{~g}$ of SDS, and was made up to $1 \mathrm{~L}$ with deionized water. This solution was diluted 10X with deionized water before being used. The new running buffer was poured into the upper compartment of the gel module and the comb was removed and the wells were washed with new running buffer.

$\mathrm{CPLA}_{2}$ is found in the cytosolic and particulate fractions. COX-1 and COX-2 are only found in the particulate fraction. Cytosolic and particulate fractions were treated with a $2 X$ loading buffer made by mixing $3800 \mu \mathrm{L}$ of deionized water, $1000 \mu \mathrm{L}$ of $0.5 \mathrm{M}$ tris (Fisher Scientific, BP-154-1, Napean, Ontario)-HCL (pH 6.8) (Fisher Scientific, A144-500), $800 \mu \mathrm{L}$ of glycerol (Fisher Scientific BP229-1), $1600 \mu \mathrm{L}$ of $10 \%$ SDS (Fisher Scientific BP166-100), $400 \mu \mathrm{L}$ of $2-$ mercaptoethanol (Fisher Scientific, BP176-100), and $400 \mu \mathrm{L}$ of $1 \%$ bromophenol blue (Sigma, B-8026, Oakville, Ontario).

The amount of sample protein loaded was taken from the mid-range of the dose response curve based on our previous study (Warford, 2003). For both cytosolic and particulate $\mathrm{CPLA}$ and particulate COX-2, $14 \mu \mathrm{g}$ of protein was loaded and for particulate COX-1,16 $\mu \mathrm{g}$, which is a little higher amount, was loaded due to the low levels of this protein. When the samples were prepared, 
they were heated at $100^{\circ} \mathrm{C}$ for 5 minutes to denature proteins, placed in an Eppendorf $5417 \mathrm{C}$ centrifuge at $7000 \mathrm{rpm}$ for 1 minute (Brinkmann Instruments, Mississuga, Ontario), and placed on ice. Then the samples were loaded into each well along with a benchmark pre-stained protein ladder in a separate lane (Invitrogen, cat no 10748-010, Burlington, Ontario). A standard was loaded in duplicate to each gel. The standard was made maxing particulate sample from all rats of each experimental group to control for gel variation across the blot. The protein migrated in running buffer in an electrophoretic chamber (Amersham Biosciences, part of Hoefer miniVE vertical electrophoresis system, 80-6418-77, Buckinghamshire, England) at $200 \mathrm{~V}$ at room temperature until the dye front just came off the gel. This took approximately 1 hour and 45 minutes.

A hydrophobic polyvinylidene fluoride (PVDF) membrane (Amersham Biosciences, Hybond-P RPN303F, Buckinghamshire, England) was cut to the proper size and labeled before the dye front ran off the gels. The lower left hand corner of the membrane was cut to indicate the first lane and the membrane was moistened with methanol (Fisher Scientific, A452-4, Napean, Ontario) for 10 seconds and then placed in deionized water on an orbital shaker (Fisher Scientific, model no 361 ) set at 90 revolutions per minute (rpm) for 7-8 minutes. The water was replaced with transfer buffer and the membrane was put back on the orbital shaker again until the gel was ready to be transferred. The transfer buffer was prepared as 10X transfer buffer that contained $29.0 \mathrm{~g}$ tris base (Fisher Scientific, BP154-1), $144.0 \mathrm{~g}$ glycine (Fisher Scientific, BP381-1), and was made up to $1 \mathrm{~L}$ with deionized water. One hundred $\mathrm{mL}$ of $10 \mathrm{X}$ transfer buffer was mixed 
with $200 \mathrm{~mL}$ methanol (Fisher Scientific, A452-4) and $700 \mathrm{~mL}$ deionized water before being used.

When the gel was finished running, the gel module was removed from the chamber and the glass plates were separated. The stacking gel was cut off using the spacer and the bottom corner by the first lane also was cut off to indicate the first lane number. The gel was equilibrated in transfer buffer for 5-10 minutes and then was placed in the transfer apparatus (Amersham Biosciences, 80-6418-96, Buckinghamshire, England) against the PVDF membrane in between two pieces of filter paper with the cut corners of the gel and membrane being aligned together. Sponges were added to both sides of the gel so that the $\mathrm{gel} / \mathrm{membrane} /$ paper was firmly sandwiched in place in the transfer apparatus. The transfer apparatus filled with transfer buffer was placed in a transfer chamber which was filled with deionized water. These proteins were transferred in the $4^{\circ} \mathrm{C}$ fridge for approximately 2 hours at $375 \mathrm{~mA}$.

After transfer, the membrane was removed from the apparatus and placed in $5 \%$ skim milk solution prepared by adding $0.5 \mathrm{~g}$ skim milk powder to $10 \mathrm{~mL} 0.1 \%$ tris base solution (TBS/Tween). The membrane was then blocked for one hour in a shallow convered dish on a rocker (Boekel Scientific Rocker II, model 260350, Feastville, Pennsylvania) at room temperature. The solution then was poured off the membrane and was covered with the primary antibody solution.

The primary antibody was prepared in $2 \%$ skim milk solution made with $0.2 \mathrm{~g}$ skim milk powder in $10 \mathrm{~mL}$ TBS/Tween. The concentration of the primary antibody was 1:250 for all proteins, which were $\mathrm{CPLA}_{2}$ (Santa Cruz Biotechnology, 
$\mathrm{N}-216$, antihuman rabbit polyclonal immunoglobulin $\mathrm{G}$ (lg G), cat. no. sc-438, California, USA), COX-1 (Cayman Chemical Company, antiovine mouse monoclonal antibody, cat. no. 160110, Ann Arbor, Michigan), and COX-2 (Cayman Chemical Company, antimouse rabbit polyclonal antibody, cat. no. 160106). These primary antibody solutions were added to the blocked membrane, the dish was covered and placed on a rocker (Sanyo GallenKamp, cat. no. IH370, APP IB 1684, Loughborough, Leicestershire, England) in the $4^{\circ} \mathrm{C}$ walk-in fridge overnight.

The next morning, the primary antibodies were removed and stored for future use. The membranes then were washed 3 times as follows: $3 \times 5$ min for both cytosolic and particulate CPLA 2 and $3 \times 10$ min for both COX-1 and COX-2, therefore, total $15 \mathrm{~min}$ and $30 \mathrm{~min}$, respectively in TBS/Tween.

The secondary antibody solutions were prepared in TBS/Tween and added to the membranes, covered and placed on a rocker for one hour at room temperature. The secondary antibody, which was conjugated to horseradish peroxidase, was made using TBS/Tween. Anti-rabbit IgG was used for cytosolic and particulate $\mathrm{CPLA}$ and COX-2 at 1:20,000 concentration (Sigma, cat no A0545). Anti-mouse $\lg G$ was used for COX-1 at 1:20,000 concentration (Sigma, cat no A-3682). The membranes were washed again with the same length of time as it was with primary antibody with TBS/Tween after one hour and then they were ready to be developed.

Two chemiluminescent substrates for horseradish peroxidase (Fisher Scientific, ChemiGlow, cat. no. 2900811, Napean, Ontario) were mixed with 
deionized water in a ratio of $1: 1: 4$ for 5 minutes. The membrane was placed on plastic wrap and the chemiuminescent mixture was distributed over the membrane and let sit for 5 minutes. After 5 minutes, the membrane covered with saran wrap was developed in using a digital imaging system (Alpha Innotech, San Leandro, California) and analyzed using computer software (AlphaEase FC).

The integrated density value (IDV) was calculated and used as a measure of the intensity of the protein band. In order to obtain IDV, the background pixels were subtracted from the protein band pixels. The IDV value was calculated by dividing the average IDV of the duplicate standards loaded on each gel. IDV are arbitrary units expressing band intensity.

\subsection{Measurement of Kidney Function}

\subsubsection{Urine Creatinine}

Urinary creatinine was measured using a colorimetric assay based on the formation of a yellow/orange color when creatinine reacts with alkaline picrate. The creatinine-picrate color fades faster than the color of other interfering substances that form color complexes with picrate when treated with an acidic solution. The amount of creatinine is proportional to the difference in color intensity, which was measured at $500 \mathrm{~nm}$ before and after adding an acidic solution. Therefore, the more creatinine in the sample, the stronger the color becomes.

Standards were made ranging from $1 \mathrm{mg} / \mathrm{dL}$ to $4 \mathrm{mg} / \mathrm{dL}$. Urine samples were diluted 20X with deionized water. Standard, sample or blank were mixed 
with $1 \mathrm{~mL}$ of a picric acid solution made by mixing 2 volumes of $0.05 \mathrm{M}$ sodium phosphate and $0.05 \mathrm{M}$ sodium borate solution with 2 volumes of $4 \%$ aqueous SDS (Fisher Scientific, BP166-100) and 1 volume of $1.3 \%$ picric acid (Sigma, cat no P6744-1GA) in a $1 \mathrm{~mL}$ cuvette. The standards and samples were incubated for 45 minutes at room temperature after the picric acid solution was added to the cuvettes. Then, the absorbance of each cuvette was then read at a wavelength of $500 \mathrm{~nm}$ using a spectrophotometer (Milton Roy, Spectronic 3000 Array). Then, $25 \mu \mathrm{L}$ of a $60 \%$ acetic acid (Fisher Scientific, A38-212) solution was added to each cuvette. The standards and samples were left to incubate for 6 minutes at room temperature and then read again at a wavelength of $500 \mathrm{~nm}$ using the spectrophotometer (Milton Roy, Spectronic 3000 Array).

The final absorbance was calculated as follows: Final absorbance $=$ Pre-acid absorbace - Post-acid absorbance. A standard curve was made in Microsoft Excel based on the final absorbance of each concentration of standard. The concentration of creatinine in the urine samples was calculated using the equation from this standard curve.

\subsubsection{Serum Creatinine}

Serum creatinine was determined using a colorimetric assay. The same principle of the assay was used to measure serum creatinine as was used to measure urine creatinine.

Serum samples were spun in the centrifuge (Eppendorf, Model No 5417C, Hanmburg, Germany) at $11,000 \mathrm{~g}$ for 6 minutes so that any fat in the serum 
would come to the top and it was removed. Then the serum was transferred to a clean $0.5 \mathrm{~mL}$ microcentrifuge tube (Fisher Scientific, cat no 05-408-128, Nepean, Ontario). Creatinine standard was made from a creatinine standard stock solution (20 mg/dL, Cayman Chemical Company, cat no 10005314, Ann Arbor, Michigan) ranging from $0.05 \mathrm{mg} / \mathrm{dL}$ to $10 \mathrm{mg} / \mathrm{dL}$.

Twenty $\mu \mathrm{L}$ of standard, serum sample, or blank were added in triplicate to wells of a 96 -well microplate. Two-hundred $\mu \mathrm{L}$ picric solution made by mixing 2 volumes of the $0.05 \mathrm{M}$ sodium phosphate and $0.05 \mathrm{M}$ sodium borate solution with 2 volumes of $4 \%$ aqueous SDS (Fisher Scientific, BP166-100) and 1 volume of $1.3 \%$ picric acid (Sigma, cat no P6744-1GA) was added to each well using a multi-channel pipette. The plate was read at $500 \mathrm{~nm}$ in the microplate reader (Molecular Devices Corporation, SpectraMax 340, Sunnyville, California). A 15\% acetic acid solution was made by mixing $1 \mathrm{~mL}$ of $60 \%$ acetic acid solution (Fisher Scientific, A38-212) with $3 \mathrm{~mL}$ of picric acid solution. Twenty $\mu \mathrm{L}$ of this solution was then added to each well using a multi-channel pipettor. The plate was again read at $500 \mathrm{~nm}$ in the microplate reader.

The final absorbance was calculated as follows: Final absorbance $=$ Pre-acid absorbance - Post-acid absorbance. Again a standard curve was made in Microsoft Excel based on the final absorbance of each concentration of standard. The concentration of creatinine in the serum samples was calculated using the equation from the standard curve. 


\subsubsection{Creatinine Clearance}

Creatinine clearance was then calculated using the equation: \{Concentration of creatinine in urine $(\mathrm{mg} / \mathrm{dL}) \times$ Urine volume $(\mathrm{mL}) /$ time $(\mathrm{min})\} /$ Concentration of creatinine in serum $(\mathrm{mg} / \mathrm{dL})$.

\subsection{Prostanoid Production and COX Activity}

Sixty $\mathrm{mg}$ of lyophilized left kidney from each rat was homogenized in $1.7 \mathrm{~mL}$ fresh Tyrodes buffer (Sigma, St. Louis, Missouri). After homogenization, $17 \mu \mathrm{L}$ of $1 \%$ Triton $X-100$ was added, vortexed for 10 seconds and the homogenate was placed on ice for 30 minutes. During this 30 minute time period the homogenate was vortexed for 10 seconds every 10 minutes. Twenty $\mu L$ of homogenate was stored at $-80^{\circ} \mathrm{C}$ for protein determination using the Bradford assay (Bradford, 1976). One hundred and eighty $\mu \mathrm{L}$ of the homogenate was aliquoted in duplicate into microcentrifuge tubes containing $20 \mu \mathrm{L}$ Tyrodes buffer with either $1 \%$ ethanol as vehicle or $0.1 \mu \mathrm{M}$ SC560 (Cayman, Ann Arbor, Michigan), which is a COX-1 selective inhibitor and incubated under the following conditions: (1) 0 min with no inhibitor for determination of endogenous levels of prostanoid production; (2) 60 min incubation at $37^{\circ} \mathrm{C}$ with no inhibitor for determination of steady-state in vitro prostanoid production; (3) 10 min incubation at $37^{\circ} \mathrm{C}$ with no inhibitor for determination of total COX activity; (4) 10 min incubation at $37^{\circ} \mathrm{C}$ with $0.1 \mu \mathrm{M}$ SC560 (Cayman, Ann Arbor, Michigan) for determination of COX-2 activity. COX1 activity was determined by the difference between total COX (condition 3 ) and COX-2 (condition 4) activities. 
The incubation conditions were determined from previous time course studies which demonstrated that the production of prostanoids is linear for the first $10 \mathrm{~min}$ of incubation, that steady-state levels of prostanoids are achieved by 30-40 min of incubation, and that a concentration of $0.1 \mu \mathrm{M}$ SC560 inhibits more than $90 \%$ of COX-1 activity but does not inhibit COX-2 at all (Warford-Woolgar et al., 2006).

After the incubation time, reactions were stopped by adding $800 \mu \mathrm{L}$ of icecold $5 \mathrm{mmol} / \mathrm{L}$ acetylsalicylic acid (ASA) to the sample incubation, vortexing and centrifuging at $12,000 \mathrm{xg}$ at $4^{\circ} \mathrm{C}$ for 5 minutes. The supernatant was removed and stored at $-80^{\circ} \mathrm{C}$ for determination of $P G E_{2}, 6$-keto $\mathrm{PGF}_{1 \mathrm{a}}$, (stable metabolite of $P \mathrm{PI}_{2}$ ), and $\mathrm{TXB}_{2}$, (stable metabolite of $\mathrm{TXA}_{2}$ ), using commercial enzyme immunoassay kits (Cayman, Ann Arbor, Michigan).

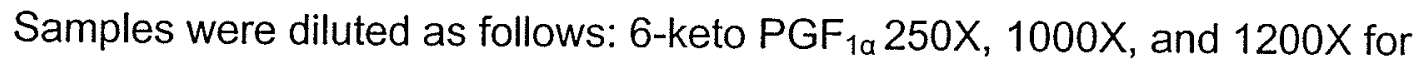
condition 1, 2 and 3, and 4, respectively; $\mathrm{PGE}_{2}$ 500X and 1000X for condition 1 and condition 2-4, respectively; and $\mathrm{TXB}_{2} 100 \mathrm{X}$ for condition 1-4. Standards ranging from 0.008 to $1 \mathrm{ng} / \mathrm{mL}$, sample, tracer, and antibody were loaded on a plate. When finished plating, the plate was covered with plastic film and incubated on a shaker for 18 hours covered with a box at the following temperature: $\mathrm{PGE}_{2}$ and 6-keto $\mathrm{PGF}_{1 \alpha}$ at $4^{\circ} \mathrm{C}$ and $\mathrm{TXB}_{2}$ at room temperature. After the incubation time, the plate was washed with $200 \mu \mathrm{L}$ of wash buffer 5 times. Then, $200 \mu \mathrm{L}$ of Ellman's reagent (Cayman, Chemical Company, Ann Arbor, Michigan) was added to each well. Again the plate was incubated on the shaker at room temperature as follows: $\mathrm{PGE}_{2}$ and $\mathrm{TXB}_{2}$ for 1 hour and 6-keto $\mathrm{PGF}_{1 \mathrm{a}}$ for 
1.5 hours. The plate was read in the microplate reader (Molecular Devices Corporation, SpectraMax 340, Sunnyville, California) at a wavelength of $412 \mathrm{~nm}$. Prostanoids were expressed relative to protein content of the homogenate. 
Appendix 7.5 Effects of dietary soy protein on urine and serum parameters in obese fa/fa Zucker rats ${ }^{1,2}$

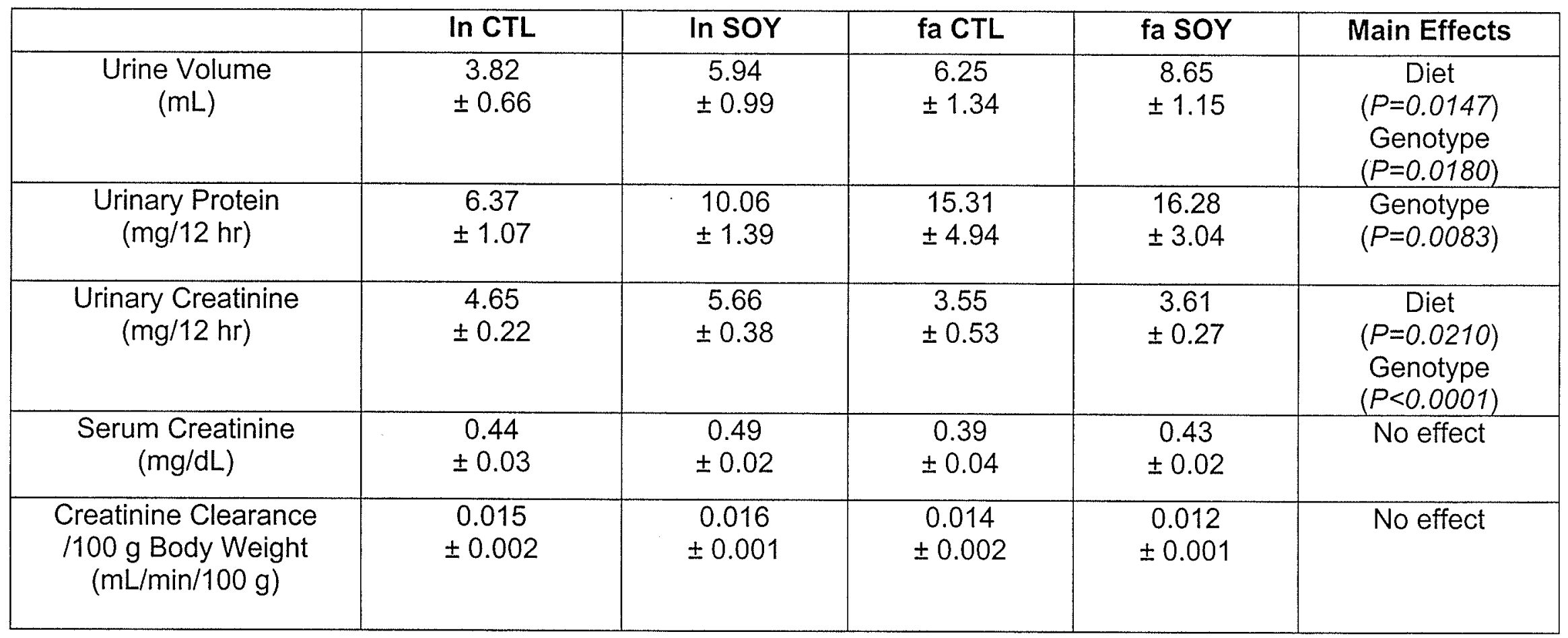

\footnotetext{
${ }^{1}$ Data is presented as mean \pm SEM ( $n=10 /$ group, except Serum Creatinine, and Creatinine Clearance/100g Body Weight where $n=8$ for In CTL group).

${ }^{2}$ Abbreviations: In CTL, lean rats fed control diet; In SOY, lean rats fed soy protein diet; fa CTL, fa/fa rats fed control diet; and fa SOY, fa/fa rats fed soy protein diet
} 